
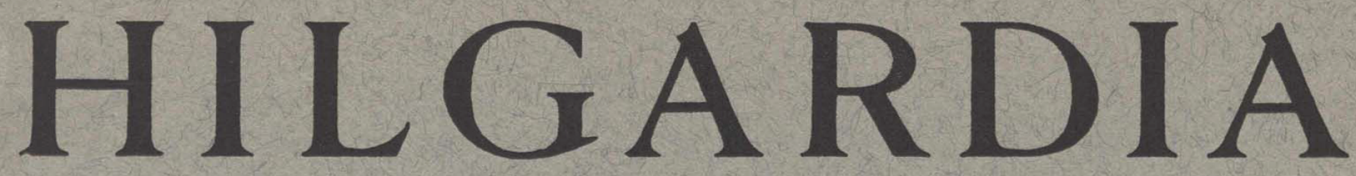

A Journal of Agricultural Science Published by the California Agricultural Experiment Station

\title{
TOXICITY OF MALEIC HYDRAZIDE IN CALIFORNIA SOILS
}

E. LEVI and A. S. CRAFTS

\section{TOXICITY OF PHENYL MERCURIC COMPOUNDS IN CALIFORNIA SOILS}

E. LEVI and A. S. CRAFTS

\section{TOXICITY OF PENTACHLOROPHENOL AND ITS SODIUM SALT IN THREE YOLO SOILS}

\author{
W. A. HARVEY and A. S. CRAFTS
}

\section{TOXICITY OF THREE 2,4-D FORMULATIONS IN CALIFORNIA SOILS \\ W. A. HARVEY}

UNIVERSITY OF CALIFORNIA - BERKELEY, CALIFORNIA 


\section{(a)}

W.

2.

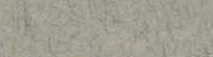

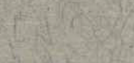

ate

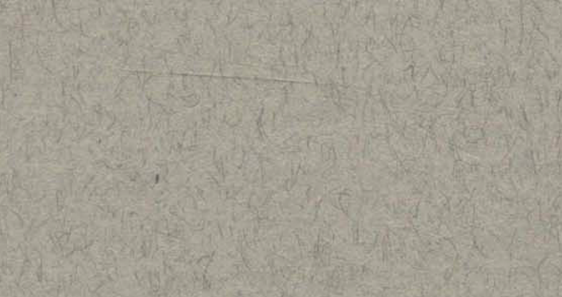

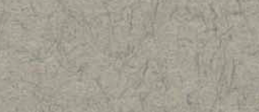

14

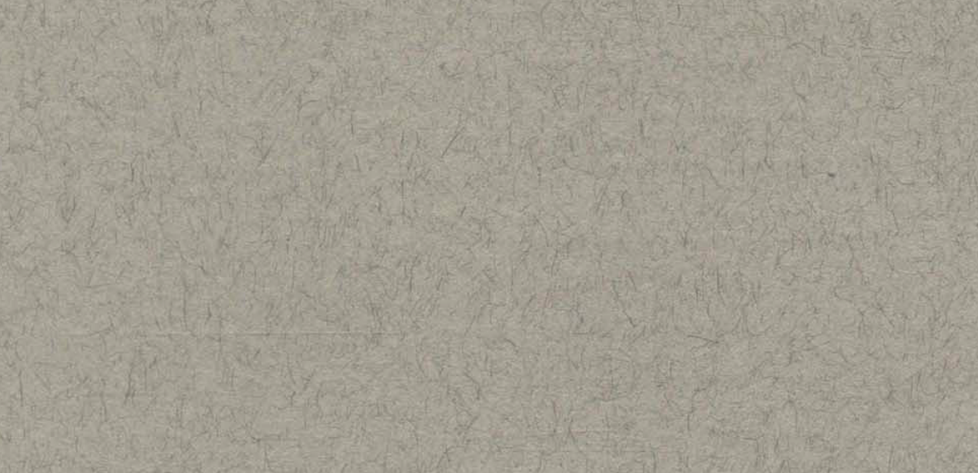

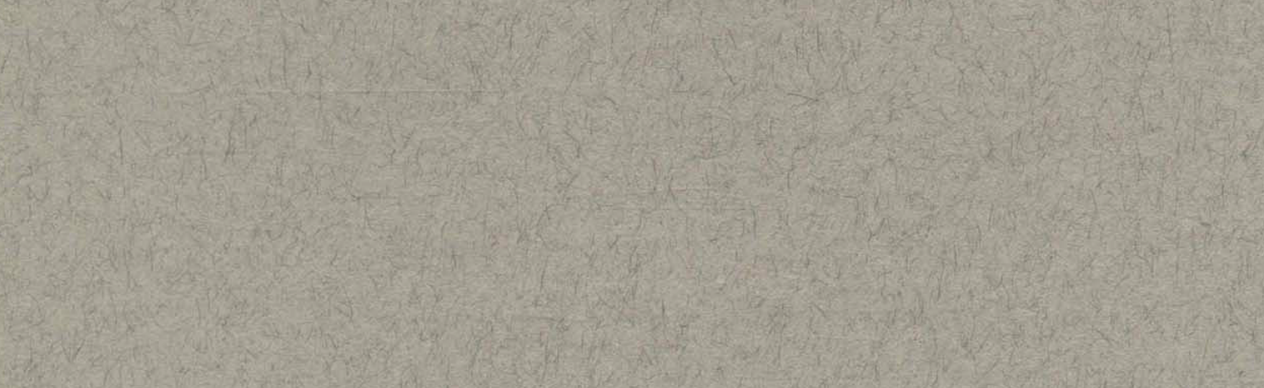

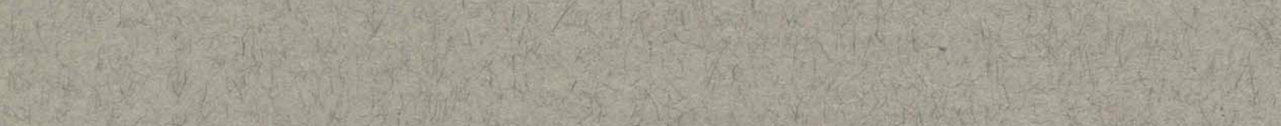

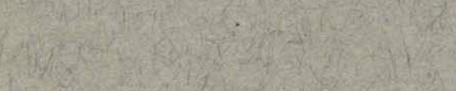

(1)

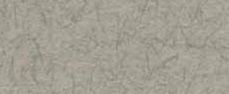

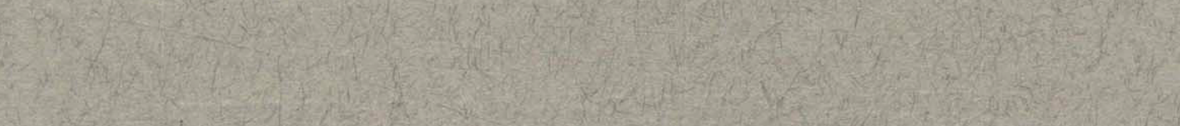

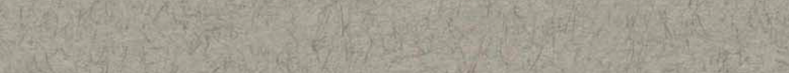

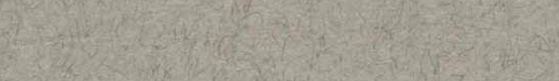

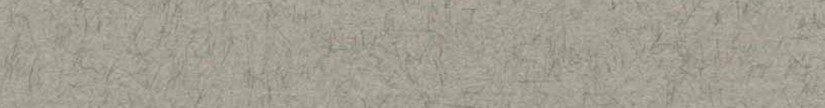

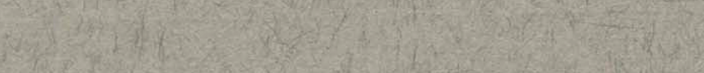

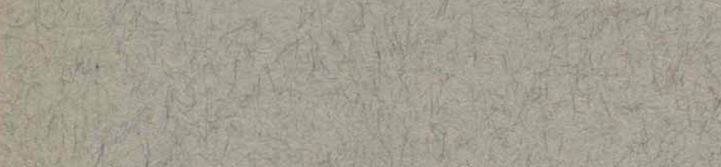

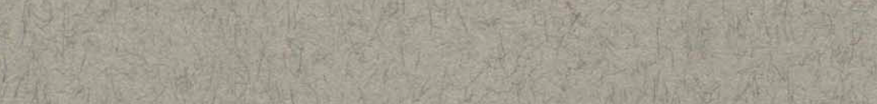




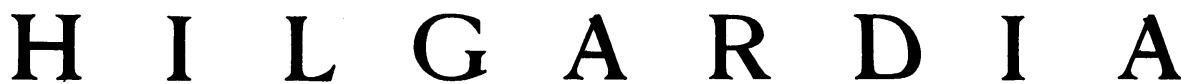

A Journal of Agricultural Science Published by

the California Agricultural Experiment Station

VoL. 21

AUGUST, 1952

No. 16

\section{TOXICITY OF MALEIC HYDRAZIDE IN CALIFORNIA SOILS ${ }^{1}$}

\section{E. LEVI ${ }^{2}$ and A. S. CRAFTS ${ }^{3}$}

\section{INTRODUCTION}

THE STUdiEs presented in this paper are an attempt to answer certain questions involved in the relations between maleic hydrazide (1,2 dihydropyridazine-3,6 dione) and different soils. These questions grew out of the fact that maleic hydrazide may acquire importance as a selective herbicide if proved successful in field tests and that spray residues left on the soil may affect subsequent crops. The studies may also indicate the value of maleic hydrazide as a temporary selective soil sterilant or as a preëmergence spray.

Maleic hydrazide when pure is a white crystalline solid, soluble 0.4 per cent in water at room temperature, and slightly acid in reaction. It has been prepared in various formulations, among which is the water-soluble diethanolamine salt (Schoene and Hoffman, 1949). ${ }^{4}$

Research already conducted on this chemical furnished some data on its effect on plant growth. Experiments by Schoene and Hoffman (1949) indicated that maleic hydrazide had temporary but strong inhibiting effects on plant growth.

Currier and Crafts (1950) in screening experiments, showed that 0.2 per cent spray killed two-weeks-old barley, yet had no apparent effect on fiveweeks-old cotton. They reported that the age of the plant was critical; for example, cotton in the cotyledon stage was severely inhibited and older grasses were less susceptible than young grasses. In general, grasses were found to be more susceptible to maleic hydrazide than broad-leaved plants; and broad-leaved plants were found to be more tolerant the more mature they were at spraying time (Crafts, Currier, and Day, 1950).

Subsequent investigations by Crafts, Currier, and Day (1950) indicated that maleic hydrazide was a growth regulator of the hormone type and could be translocated by plants.

\footnotetext{
${ }^{1}$ Received for publication November 3, 1950.

${ }^{2}$ Formerly Senior Laboratory Assistant, Division of Botany in the Experiment Station, Davis.

${ }^{3}$ Professor of Botany and Botanist in the Experiment Station, Davis.

"See "Literature Cited" for citations referred to in the text by author and date.
} 
Naylor and Davis (1949), observing a large accumulation of sugar in the leaves and stems, as well as development of anthocyanin pigments, suggest that possibly maleic hydrazide exerts its effects on plant metabolism, primarily through a disruption in the sugar breakdown and utilization. The appearance of sugar exudates on the leaves of sprayed plants was observed independently on barley (var. Sacramento) at the University of California, Davis, and development of anthocyanin pigmentation was also reported by Currier and Crafts (1950). Currier, Day, and Crafts (1951) have reported an accumulation of fructosan in barley leaves and have shown that the exudate from barley leaves is largely sucrose. Crafts, Currier, and Day (1950) showed that applications of maleic hydrazide are additive and that breakdown of the chemical, once it has been absorbed by the plant, is slow.

The work presented in this study aimed at determining:

1. The initial toxicity of maleic hydrazide in various California soils and the change in toxicity as the soils were repeatedly cropped

2. The effects of percolation on the distribution of the compound in columns of air dry soil

3. The possibility of leaching the chemical at depths where it would not cause damage to crops subsequently grown.

\section{MATERIALS AND METHODS}

Diethanolamine salt was used in all the tests interpreted in this study. The chemical was prepared by the Naugatuck Chemical Division of the United States Rubber Company at Naugatuck, Connecticut. Kanota oats was used as a plant indicator in all the tests. One experiment used one soil type (Yolo clay loam), the same range of concentration of maleic hydrazide, and different plant indicators. The results of this test are shown in table 6 .

The principal characteristics of the soils used can be summarized according to Storie and Weir (1948) and to Cole (1949) as follows:

\begin{tabular}{|c|c|c|c|c|c|}
\hline Soil series & General reaction & Parent material & Order & Class & Great soil group \\
\hline Aiken & Slightly acid & Basic igneous & Zonal & Pedalfer & $\begin{array}{l}\text { "Podzolic" (from } \\
\text { lateritic ma- } \\
\text { terial) }\end{array}$ \\
\hline Arbuckle & Neutral & Sedimentary & Azonal & Pedalfer & Alluvial \\
\hline Egbert & Slightly acid & Mixed organic & $\begin{array}{l}\text { Intra- } \\
\text { zonal }\end{array}$ & Pedalfer & Bog \\
\hline Hanford & Neutral & Acid igneous & Azonal & $\begin{array}{l}\text { Noncalcareous } \\
\text { pedocal }\end{array}$ & Alluvial \\
\hline Rocklin & Slightly acid & Acid igneous & $\begin{array}{l}\text { Intra- } \\
\quad \text { zonal }\end{array}$ & $\begin{array}{l}\text { Noncalcareous } \\
\text { brown }\end{array}$ & Planosol \\
\hline Sierra & Moderately acid & Acid igneous & Zonal & Pedalfer & Podzolic \\
\hline Stockton & Basic & Basic igneous & $\begin{array}{l}\text { Intra- } \\
\text { zonal }\end{array}$ & Pedocal & Wiesenboden \\
\hline Yolo & Neutral & Sedimentary & Azonal & $\begin{array}{l}\text { Noncalcareous } \\
\text { pedocal }\end{array}$ & Alluvial \\
\hline
\end{tabular}

All of these soils were air dry samples, pulverized and screened before use. These studies were carried out in the greenhouse under partially controlled conditions. 


\section{TOXICITY TESTS}

The tests were conducted by the methods first described by Crafts (1935). The advantages of such methods led to their use by Crafts in a number of subsequent works and by Schwendiman (1941) in studying the relations between soils and various herbicides.

Preliminary series were set up. These consisted of four replicates, in which Yolo fine sandy loam and concentrations of $0.0,1.0,10.0,100.0,1,000.0$, $5,000.0$, and 10,000.0 p.p.m. maleic hydrazide (air dry soil basis) were used. The results of repeated croppings are shown in table 1.

Subsequently, three replicated series were grown on 11 soils. In these series different concentrations in a smaller range were used: 0.0, 5.0, 15.0, 40.0, 80.0, $140.0,220.0,340.0,490.0$, and 680.0 p.p.m. maleic hydrazide in the air dry soil.

The chemical was measured from a stock solution, diluted to a total volume sufficient to bring the soil in the can to its field capacity, and added in three increments. The cans were not perforated ; therefore no loss of chemical occurred during watering, which was done by weight.

Thirty days after planting, the crop was cut off at ground level, its height measured, and its fresh weight recorded. When the first crop was harvested; the tops of the plants were returned to each can. After 30 days, the dried soil was pulverized, the tops placed in the empty cans, and the soil poured in. The cultures were then watered to field capacity and seeded to determine changes in toxicity. The procedure was repeated, and three croppings were made in each instance.

The results of this test are shown in figures 1 to 11 and in table 12. As table 2 indicates, no correlation could be found between toxicity and clay content.

Comparison of fresh weights of original crop yields of controls for the different soils in table 3 shows no consistent relation between fertility level and toxicity or subsequent inactivation of maleic hydrazide.

To reach these conclusions, Kanota oats, germinated and grown in quartz sand to a height of about $5 \mathrm{~cm}$ were transplanted and grown in water-culture solutions. In painted quart Mason jars three fertility levels were set up, equivalent to $0.5,1.0$, and 2.0 complete Hoagland solution (Hoagland and Arnon, 1950). The following amounts of maleic hydrazide were added: 0.0, 5.0, 15.0, 40.0, 80.0, 140.0, 220.0, 340.0, 490.0, and 680.0 p.p.m., culture solution basis.

The reaction of the solutions was checked at regular intervals with universal indicator paper and found to be slightly acid ( $\mathrm{pH}$ about 6.0). Five oat plants were transplanted in each instance; no provision was made for aeration. Separate jars provided with aeration did not show any difference in toxicity. After 15 days, all plants at concentrations above 40.0 p.p.m. were dead and dried. Mildew, which appeared about 20 days after start of the cultures, was particularly abundant on the 5.0 p.p.m. cultures compared with the controls. No dusting application was made.

After 30 days total fresh weights were recorded; no difference in toxicity was found among the three fertility levels.

Table 4 shows that the reaction of the soil did not seem to affect either the initial toxicity or the inactivation of maleic hydrazide. Similarly, as shown by 
table 5 , no relation could be found between the per cent water in the soils at field capacity and the chemical toxicity.

The effect of nitrate concentration was investigated by leaching columns of Yolo clay. loam with water, and comparing the toxicity of maleic hydrazide in this soil, now presumably low in nitrates, with normal Yolo clay loam. No difference was found in the first cropping, and no significant divergences occurred subsequently.

Results indicated an increase in fertility in such soils as Aiken clay loam, Yolo adobe clay, and Stockton adobe clay during the first cropping, at very low concentrations of maleic hydrazide. Increase in yield from treated soils, compared with yield from untreated soils is very apparent in all soils during the second and third croppings. One exception is Arbuckle clay loam, which showed an increase in yield only at the third cropping. Even though we have to account for mineral nutrients not utilized yet still available in the soils in which little or no growth occurred in the previous crop, there is a clear indication that the inactivation of maleic hydrazide is accompanied by an increase in fertility. This may be due to nitrogenous compounds made available through the hydrolysis or microörganic decomposition of the chemical. The salt used was a diethanolamine, and the acid itself contains two - NH groups.

It has been suggested that the iron from the tin cans might be a factor in the decomposition of maleic hydrazide in these tests since it is known that iron salts of the compounds have not been successfully synthesized because of instability. This factor probably caused no error in the experiments considered here, as the degree of rust varied according to the condition of the cans used and some cans were new and unrusted. Triplicates were used, and had the factor of rust actually caused error, this would have appeared in the course of the experiment, but actually did not.

It is perhaps worth noting that yields smaller than $0.1 \mathrm{gm}$ were considered negligible. Such cultures were considered sterile; oat plants did germinate, but showed no subsequent growth. When growth inhibition occurred, only the first leaf of the oat plant showed anthocyanin pigmentation at harvest time.

Egbert loam behaved erratically, yet when leached with large quantities of water behaved normally. Results are reported in figure 9 and table 12. This same soil did not behave anomalously in other experiments carried out in the greenhouse, and no explanation is offered, except perhaps that a high salt concentration may have accumulated in the particular sample used here.

From the previous discussion and a consideration of the soils and conditions under which they were studied, it may be stated that maleic hydrazide in soils varies in toxicity. Sterility was obtained from 15.0 to 140.0 p.p.m., air dry soil basis, and the inactivation after two months under greenhouse conditions varied from slight to complete in the range of concentrations considered. These initial and residual toxicities seemed inherent to each soil and not due to any common characteristic.

The initial toxicity of maleic hydrazide in Yolo clay loam to various plant indicators is shown in table 6 , and plate 1 .

As can be seen, at 5.0 p.p.m. maleic hydrazide there was an increase in weight in four instances-flax, sunflower, watergrass, and watermelon-com- 
pared with check yields. This increase, however, is probably significant only for watergrass and watermelons.

\section{DISTRIBUTION OF MALEIC HYDRAZIDE IN SOIL COLUMNS}

The procedure followed in this test (Crafts, 1935) included the use of celluloid soil tubes filled with air dry soil and moistened from above by a constant flow of stock solution. No water accumulated on the top, and none ran down the sides of the column. Chemical sufficient to sterilize the whole column was diluted in enough water to wet all the soil. There was practically no loss of soil solution. After complete moistening, the tubes were left for 24 hours to reach equilibrium before being opened and cut into 10 equal portions. Each portion was mixed, with care taken to reduce puddling of the wet soil. Each portion was placed in a no. 2 can and seeded with Kanota oats. Controls of the different soils were set up simultaneously. After 30 days the tops were cut off ; and the procedure that was used in recropping the toxicity series was also used in this test.

The six soils tested were Sierra fine sandy loam, Yolo fine sandy loam, Hanford loam, Aiken clay loam, Yolo clay loam, and Stockton adobe clay. Except for the Aiken clay loam, the behavior of these soils was quite similar.

Tables 15 and 16 show the results of these tests. As was expected from the conclusions reached in the toxicity determination, no maleic hydrazide fixation occurred on the clay particles. The chemical moved with the soil solution, was available to plants, and inhibited all growth in the whole column.

In the Aiken clay loam, however, only the top $30 \mathrm{~cm}$ showed no growth, which indicated an accumulation of available maleic hydrazide in this region. The behavior of this soil indicates that in the soil solution maleic hydrazide behaves as an anion. This would also confirm its repulsion by clay particles. Murphy (1939) showed the very large phosphate fixation of Aiken clay loam. He was able to fix 2,372 $\mathrm{mg}$ of phosphate per $100 \mathrm{gm}$ of soil. He also showed an increase in the base exchange capacity with increase in phosphate fixation in kaolinite. Aiken soils are supposed to have a kaolinitic clay structure. It was thought, therefore, that by saturating a column of Aiken clay loam with phosphate no fixation of maleic hydrazide would occur, unless it could displace the phosphate from the kaolinitic structure. Phosphate was added at a rate of $2,840 \mathrm{mg}$ per $100 \mathrm{gm}$ of soil as $\mathrm{KH}_{2} \mathrm{PO}_{4}$. Excess phosphate was leached with 1,000 ec of water, then maleic hydrazide was added. No fixation was observed. The chemical moved with the soil solution, and no growth was obtained in any increment of the column (tables 13 and 14 and plate 2).

The fact that maleic hydrazide could not displace phosphate adsorbed on the Aiken soils was thought to be an important factor in the inactivation of the chemical by displacement through these kaolinitic soils. The procedure was then reversed, that is, maleic hydrazide was added, then $2,840 \mathrm{mg}$ of phosphate per $100 \mathrm{gm}$ of soil. The herbicide was displaced to a certain extent; moving ahead of the phosphate, it was able to fix itself on the soil, inhibiting all growth in the top $60 \mathrm{~cm}$ of the column. The phosphate, however, did not displace the maleic hydrazide completely, and growth was normal in the lower $40 \mathrm{~cm}$ of the column. 
It is worth noting that after treatment the Aiken soil lost its characteristic granulation and acquired a small crumblike structure. Also, evaporation was much faster in treated than in untreated soils. These points were not investigated and no explanation is offered.

As will be shown later, subsequent investigations proved that water alone could displace maleic hydrazide from soils, including Aiken clay loam. The same quantity of water $(1,500 \mathrm{cc})$ displaced the maleic hydrazide toxicity region from 0-30 to $30-60 \mathrm{~cm}$ depth, growth being normal in the top $30 \mathrm{~cm}$ fraction. The fact that no maleic hydrazide was leached out is confirmed by the cultures grown in the collected soil leachates mentioned later, which showed no sign of inhibition or toxicity. The unexpected difference between the behavior of maleic hydrazide in Aiken clay loam when leached with water or with $\mathrm{KH}_{2} \mathrm{PO}_{4}$ remains unexplained. Large amounts of water seem to inactivate maleic hydrazide, with a simultaneous increase in fertility of the soil, which can be ascribed to a possible hydrolysis of the chemical. Columns of Aiken clay loam leached with 1,500 cc of water yielded 3.9, 3.0, and $2.6 \mathrm{gm}$ of plants respectively for the first, second, and third increments of soil, as compared with $2.4 \mathrm{gm}$ for the control. When the same volume of $\mathrm{KH}_{2} \mathrm{PO}_{4}$ solution was added, no growth occurred in any of these increments (control gave $2.6 \mathrm{gm}$ ).

In Aiken clay loam a close relation exists between maleic hydrazide displacement, inactivation, and $\mathrm{KH}_{2} \mathrm{PO}_{4}$ solution or any of its ions. The nature of this relation remains to be determined.

The very large quantity of $\mathrm{KH}_{2} \mathrm{PO}_{4}$ used (1,500 ce of $1.5 \mathrm{M}$. solution) might suggest that the osmotic pressure of the soil solution, the potassium toxicity, or the $\mathrm{pH}$ change caused by anion exchange in kaolinite are influencing factors in the sterility shown by this treated soil. While these factors actually may be entering into the picture, they should not be given more importance than they deserve, because the bottom $40 \mathrm{~cm}$ of soil (60 to $100 \mathrm{~cm}$ depth), which were submitted to the same treatment, showed growth very similar to the untreated control. However, no actual osmotic pressure, $\mathrm{pH}$, or available $\mathrm{K}$ determinations were made during this experiment.

The fact that Aiken clay loam is a soil with a high Fe content was also considered. Another soil, the Sierra fine sandy loam, which, according to Shaw (1937), is high in Fe content, was investigated. It did not behave like the Aiken, but was similar to the other soils.

Second croppings show a certain increase in fertility in the top parts of the columns of most soils. This can be attributed to breakdown of the chemical after 60 days. In the instances where the chemical was presumably equally distributed, not being fixed, this increase in fertility in the top parts of the columns may indicate a certain amount of hydrolysis occurring as the chemical solution gets into contact with the soil. This is very clear in Hanford loam.

The test of second croppings showed very poor growth in Yolo clay loam and "Yolo clay loam, nitrate free" series. No explanation is offered, for in the toxicity series 680 p.p.m. of maleic hydrazide were inactivated in Yolo clay loam in a period of 60 days, whereas in the percolation test reported here 220.0 p.p.m. were not. Plant leaves showed typical growth inhibition and anthocyanin pigmentation. 
Increasing the concentrations of herbicide added to Aiken clay loam increased further the quantity of soil sterilized, indicating an adsorption mechanism for maleic hydrazide fixation. The fact is that 220.0 p.p.m. sterilized $30 \mathrm{~cm}, 440.0$ p.p.m. sterilized $50 \mathrm{~cm}$, and 880.0 p.p.m. sterilized $70 \mathrm{~cm}$. Thus, doubling the concentration after the first 220.0 p.p.m. increased the sterilized area by two thirds the original amount, and doubling still further increased the sterility in about the same proportion.

\section{LEACHING EXPERIMENTS}

The two soils used were Yolo fine sandy loam and Aiken clay loam. The method was similar to that used in the study of the distribution of the chemical. After being wetted with maleic hydrazide solution, the soil columns respectively were leached with 2,500 and $1,500 \mathrm{cc}$ of water. The results appear in tables 17 and 18.

It is clear that water alone can displace maleic hydrazide in the soil columns. Large quantities are needed, but displacement is possible even in the Aiken clay loams that are able to fix the herbicide on their clay colloid. It was shown that by using 200 and 300 surface $\mathrm{em}$ of water, maleic hydrazide could be moved lower down and clear out of a 100-cm-long column of Aiken clay loam. Worth noting is the fact that to bring to field capacity these columns of soil, $1,500 \mathrm{cc}$ of water are needed. The term "surface $\mathrm{cm}$ of water" is used here in the sense given to it by Crafts (1935). It indicates the equivalent of water added in $\mathrm{cm}$ on top of the column, and it determines the total depth of soil that could be brought to field capacity by the quantity of water added. It is evident that the same number of "surface cm of water" for different soils may be equivalent to varying depths of moistening.

The fact that the top fractions of the Yolo fine sandy loam showed such an increase in fertility (15.4 gm against $6.7 \mathrm{gm}$ for the check) when 2,500 ec of water-for instance, 150 surface $\mathrm{cm}$ - had passed through, indicated a fairly rapid breakdown of the chemical, probably through hydrolysis. This hydrolytic effect may be similar to that of $\mathrm{CaCN}$ in soils. Water alone does not decompose maleic hydrazide. This fact is supported by the water-culture experiments in which no apparent inactivation occurred.

The hydrolysis of maleic hydrazide in soils-if it is such-seems repressed by large quantities of $\mathrm{KH}_{2} \mathrm{PO}_{4}$ in Aiken soils, at least as reported in this paper.

After 60 days the unleached column showed some inhibition in the top 10 cm fraction, indicating a difference in behavior when such large quantities of water are in contact with the chemical compound in the soil. This increase in yield did not occur in the same proportion in the Aiken clay loam, where 1,500 cc of water were made to percolate through the column after the addition of maleic hydrazide.

The leachates from these columns were collected in 350.0 ec increments, and one-week-old Kanota oats, which were germinated in quartz sand, were transplanted and grown in these solutions. Checks of complete Hoagland solution and distilled water were set up simultaneously. Results correlated the biological assays (plates 3 and 4 ). Toxicity was present only in the Yolo-soil solutions, where the second leaf growth was inhibited, and where anthocyanin 
pigmentation was apparent. After 30 days the plants had not died, and fresh and dry weights are shown in table 7.

The surprising fact that root growth was inversely proportional to shoot development where maleic hydrazide was present was later noticed in the toxicity series using water culture solutions. Roots were stunted and had developed laterals while the shoots kept on developing. When the shoot growth was completely inhibited, roots lengthened, but no laterals appeared. Actual values are shown in table 8.

Measurements of leaf elongation over the 30-day period indicated that at 5.0 p.p.m., the first and second leaves steadily grew faster than the controls, the third leaf lagged, and the fourth leaf never developed. The values recorded are shown in table 9.

Subsequent investigations with water cultures using $0.0,0.5,1.0,2.5,10.0$, and 20.0 p.p.m. maleic hydrazide, nutrient culture solution basis, and the method described previously, produced the results that are shown in table 10.

As these values show, 0.5 and 1.0 p.p.m. maleic hydrazide actually acted as a stimulant for both roots and shoots. Again, elongation of roots at concentrations where inhibition occurred was in inverse relation to shoot elongation, as shown by table 11 .

\section{CONCLUSIONS}

From the studies reported in this paper, maleic hydrazide appears to be a "unique growth regulant." Its behavior in soils is not similar to that of any herbicide whose soil relations have been studied. There seems to be no simple relation between toxicity and soil characteristics among the 11 soils studied.

Toxicity was highest and inactivation slowest in Arbuckle clay loam, 15.0 p.p.m. being toxic originally and 340.0 p.p.m. still causing complete sterilization five months later. Sterility was obtained at 140.0 p.p.m. in four soils. This was the least degree of toxicity in the original tests. Inactivation was fastest in Aiken clay loam, where 680.0 p.p.m. were not toxic three months later. In Yolo fine sandy loam, 5,000 p.p.m. were still inhibiting all growth seven months after application.

These soils were kept moist during crop growth but dry between crops. The greenhouse was heated, so the temperatures were fairly constant and the soils were under what can be termed "warm" conditions throughout.

Percolation experiments showed that in soils where anion exchange is predominant-for instance, Aiken clay loam-maleic hydrazide was held to the clay component, while it moved freely with the soil solution in all the other soils studied.

Leaching experiments showed that the chemical could be displaced downward, but relatively large quantities of water were required.

Schoene and Hoffman (1949) mentioned that "applied to the soil as a drench much more chemical was found necessary to inhibit growth of tomato plants than when applied as a spray, indicating that entry through the leaves is more rapid than through the roots." While this statement may hold true for tomatoes, we can say that this was not found when oats were grown in California soils. As low as 15.0 p.p.m. were toxic in some soils and in water cultures 5.0 p.p.m. showed inhibiting effects on oats. The rate of absorption also was 
faster in the water culture solutions, where young oats showed toxicity signs four days after transplanting, while plants of barley (20 days old) leafsprayed, showed clear, visible signs of toxicity only 15 days after treatment.

The Naugatuck Chemical Division (1949) suggested the use of six pounds of 30 per cent diethanolamine salt in 100 gallons of water, to retard grasses in general. This is 0.24 per cent salt basis. In the greenhouse tests, selectivity was obtained with a 0.2 per cent salt basis solution (Crafts and Currier, 1950).

As far as direct applications to the soil are concerned, a 0.2 per cent solution-for instance, 2,000 p.p.m.-in some of the soils we have studied would probably inhibit completely all new growth for at least 30 days. A 25 ce volume of a 2,000 p.p.m. solution (average of amounts sprayed on foliage) would be equivalent to 100.0 p.p.m. applied to the soil in any of our toxicity determinations.

It is possible and probable that older plants would react differently from seedlings where root absorption is concerned. Crafts, Currier, and Day (1950) showed that toxicity to sprayed plants was related to age of the plants.

The results obtained in these experiments tend to confirm the findings of Crafts, Currier, and Day (1950) that maleic hydrazide was translocated, and that when absorbed by the plant it does not break down rapidly. No recovery was observed in any instance in a 30-day period, in plants that had absorbed some chemical and showed growth inhibition signs.

The observations of Currier and Crafts (1950) and Naylor and Davis (1949) that anthocyanin pigmentation was an apparent sign of maleic hydrazide toxicity on treated plants were also true here when the chemical was absorbed through the roots.

Broad-leaved plants at the germinating stage were not more resistant than oats, and it is difficult to draw any conclusion for this part of the experiment.

The preceding discussion shows clearly that maleic hydrazide residues would not constitute a problem in most California soils. Leaching through precipitation may be effective. There are indications that this chemical decomposes fairly rapidly under moist, warm conditions, and may act as a fertilizer.

These greenhouse experiments also show that maleic hydrazide can sterilize the soil against plant growth if used in large enough quantities. However, it decomposes too readily under the conditions mentioned to be considered an effective temporary soil sterilant. 


\section{LITERATURE CITED}

CoLE, R. C. 1949. Reaction of California soils. California Agr. Exp. Sta. Bul. 712:1-18.

Crafts, A. S.

1935. The toxicity of sodium arsenite and sodium chlorate in four California soils. Hilgardia 9:461-98.

1939. The relation of nutrients to toxicity of arsenic, borax, and chlorate in soils. Jour. Agr. Res. 58:637-71.

Crafts, A. S., H. B. Currier, and B. E. Day.

1950. Response of several crop plants and weeds to maleic hydrazide. Hilgardia 20: $57-80$.

Currier, H. B., and A. S. Crafts.

1950. Maleic hydrazide, a selective weed killer. Science 111:152-53. February 10.

Currier, H. B., B. E. DaY, and A. S. Crafts.

1951. Some effects of maleic hydrazide on plants. Bot. Gaz. 112:272-80.

Hoagland, D. R., and D. I. ARnon.

1950. The water culture method for growing plants without soil. California Agr. Ext. Cir. 347:1-32. (Revised)

MURPHY, H. F.

1939. Role of kaolinite in phosphate fixation. Hilgardia 12:343-79.

NAYLOR, A. W., and E. A. DAvis.

1949. Some effects of maleic hydrazide on growth and respiration of representative monocots and dicots. In mimeographed abstract Amer. Soc. of Plant Physiologists, 24th annual meeting. New York City. December 26-30.

Naugatuck Chemical Division.

1949. Mimeographed communication, October 18.

Schoene, D. L., and O. L. Hofrman.

1949. Maleic hydrazide, a unique growth regulant. Science 109:588-90. June 10.

Schwendiman, A.

1941. Toxicity and decomposition of sodium chlorate in soils. Amer. Soc. Agron. Jour. 33:522-37.

Shaw, C. F.

1937. Some California soils and their relationship. University of California syllabus, J.D.: 1-117.

STORIE, R. E., and W. W. WEIR.

1948. Manual for identifying and classifying California soil series. $58 \mathrm{pp}$. Assoc. Students Store, University of California. 
TABLE 1

Fresh Weights of Kanota Oat Plants Grown in Yolo Fine Sandy loam at Various Concentrations of Maleic Hydrazide (Values are averages of four replicates)

\begin{tabular}{|c|c|c|c|c|c|}
\hline \multirow{2}{*}{$\begin{array}{l}\text { Concentration } \\
\text { of maleic hydrazide } \\
\text { in p.p.m. } \\
\text { (air dry soil basis) }\end{array}$} & \multicolumn{5}{|c|}{ Fresh weights of plants grown in Yolo fine sandy loam } \\
\hline & First crop & Second crop & Third crop & Fourth crop & Fifth crop \\
\hline & $(\mathrm{gm})$ & $(\mathrm{gm})$ & $(g m)$ & $(g m)$ & $(g m)$ \\
\hline $0: 0 \ldots \ldots \ldots \ldots$ & 8.7 & 5.1 & 5.5 & 4.5 & 5.9 \\
\hline $100.0 \ldots$ & 0.0 & 11.7 & 8.5 & 4.5 & 6.6 \\
\hline $1,000.0$ & 0.0 & 0.0 & 5.2 & 12.6 & 9.3 \\
\hline $5,000.0$ & 0.0 & 0.0 & 0.0 & 0.0 & 0.0 \\
\hline $10,000.0 \ldots \ldots \ldots \ldots \ldots \ldots \ldots$ & 0.0 & 0.0 & 0.0 & 0.0 & 0.0 \\
\hline
\end{tabular}

TABLE 2

Toxicity of Maleic Hydrazide in Some California SoIls ARRANGed IN ORDER OF InCREASING Clay Content (Values are averages of three replicates)

\begin{tabular}{|c|c|}
\hline Soil & $\begin{array}{l}\text { Sterility obtained } \\
\text { at: }\end{array}$ \\
\hline Yolo fine sandy loam.. & $\begin{array}{c}(\text { p.p.m. }) \\
80.0\end{array}$ \\
\hline Hanford loam......... & 80.0 \\
\hline Aiken clay loam..... & 140.0 \\
\hline Yolo clay loam. ........... & 220.0 \\
\hline Stockton adobe clay. ........ & 140.0 \\
\hline
\end{tabular}

TABLE 3

TOXicity of Maleio Hydrazide in 10 California SoIls, ARRANGed in ORDER OF INCREASING FERTILITT (Values are averages of three replicates)

\begin{tabular}{|c|c|c|c|c|}
\hline \multirow{2}{*}{ Soil } & \multirow{2}{*}{$\begin{array}{l}\text { Original } \\
\text { crop yield of } \\
\text { control }\end{array}$} & \multicolumn{3}{|c|}{ Sterility obtained at: } \\
\hline & & First crop & Second crop & Third crop \\
\hline Arbuckle clay loam..$\ldots \ldots \ldots \ldots \ldots \ldots$ & $\begin{array}{c}(\text { fresh } w t, g m) \\
0.8\end{array}$ & $\begin{array}{c}\text { (p.p.m.) } \\
15.0\end{array}$ & $\begin{array}{c}\text { (p.p.m.) } \\
80.0 \\
\text { higher than }\end{array}$ & $\begin{array}{c}\quad(p . p . m .) \\
340.0 \\
\text { higher than }\end{array}$ \\
\hline Aiken clay loam $\ldots \ldots \ldots \ldots \ldots \ldots \ldots \ldots$ & 2.7 & 140.0 & 680.0 & 680.0 \\
\hline Rocklin fine sandy loam............. & 2.7 & 140.0 & 680.0 & $\begin{array}{c}680.0 \\
\text { higher than }\end{array}$ \\
\hline Stockton adobe clay................ & 3.9 & 140.0 & $\begin{array}{c}490.0 \\
\text { higher than }\end{array}$ & $\begin{array}{c}680.0 \\
\text { higher than }\end{array}$ \\
\hline Sierra fine sandy loam.... & 4.0 & 80.0 & 680.0 & 680.0 \\
\hline Hanford loam................ & 5.7 & 80.0 & 220.0 & 680.0 \\
\hline Yolo adobe clay.............. & 6.6 & 140.0 & 340.0 & 680.0 \\
\hline Yolo fine sandy loam....... & 7.5 & 80.0 & 490.0 & 680.0 \\
\hline Hanford fine sandy loam. . & 8.4 & 40.0 & $\begin{array}{c}490.0 \\
\text { higher than }\end{array}$ & $\begin{array}{c}680.0 \\
\text { higher than }\end{array}$ \\
\hline Yolo clay loam. & 8.9 & 220.0 & 680.0 & 680.0 \\
\hline
\end{tabular}


TABLE 4

Toxicity of Maleic Hydrazide in Some California Solls ARranged in ORDER OF INCREASING PH REACTION (Values are averages of three replicates)

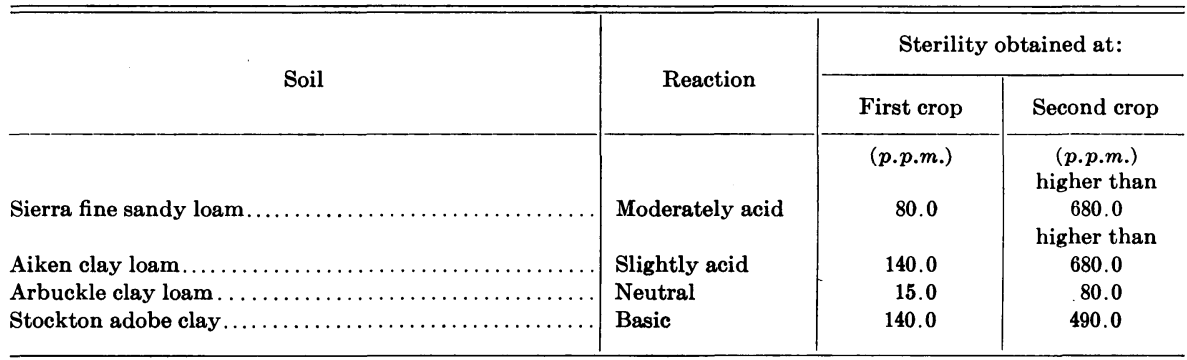

\section{TABLE 5}

Toxicity of Maleic Hydrazide in Some California Solls Arranged in Order of InCReasing Water-Holding Capacity at Their Saturation Point

(Values are averages of three replicates)

\begin{tabular}{|c|c|c|c|}
\hline \multirow{2}{*}{ Soil } & \multirow{2}{*}{ Water } & \multicolumn{2}{|c|}{ Sterility obtained at: } \\
\hline & & First crop & Second crop \\
\hline & (per cent) & (p.p.m.) & $\begin{array}{c}(p . p . m .) \\
\text { higher than }\end{array}$ \\
\hline Sierra fine sandy loam $\ldots \ldots \ldots \ldots \ldots \ldots \ldots \ldots \ldots \ldots$ & 13.5 & 80.0 & 680.0 \\
\hline 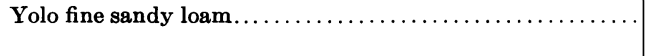 & 15.0 & 80.0 & $\begin{array}{c}490.0 \\
\text { higher than }\end{array}$ \\
\hline Aiken clay loam............... & 21.3 & 140.0 & $\begin{array}{l}680.0 \\
\text { higher than }\end{array}$ \\
\hline Yolo clay loam $\ldots \ldots \ldots \ldots \ldots \ldots \ldots \ldots \ldots \ldots \ldots \ldots \ldots \ldots \ldots \ldots \ldots \ldots$ & 30.0 & 220.0 & 680.0 \\
\hline Stockton adobe clay $\ldots \ldots \ldots \ldots \ldots \ldots \ldots \ldots \ldots \ldots \ldots \ldots \ldots$ & 32.0 & 140.0 & 490.0 \\
\hline
\end{tabular}




\section{TABLE 6}

Fresh Weights of Different Plant Indicators Grown in Yolo Clay Loam at Various Concentrations of Maleic Hydrazide

(Values are results of first cropping)

\begin{tabular}{|c|c|c|c|c|c|c|c|c|c|c|}
\hline \multirow{2}{*}{ Indicator plant* } & \multicolumn{10}{|c|}{ Concentration of maleic hydrazide in Yolo clay loam, p.p.m. air dry soil } \\
\hline & 0.0 & 5.0 & 15.0 & 40.0 & 80.0 & 140.0 & 220.0 & 340.0 & 490.0 & 680.0 \\
\hline & $(w t, g m)$ & $(w t, g m)$ & $(w t, g m)$ & $(w t, g m)$ & $(w t, g m)$ & $(w t, g m)$ & $(w t, g m)$ & $(w t, g m)$ & $(w t, g m)$ & $(w t, g m)$ \\
\hline $\begin{array}{l}\text { Bluegrass }(10) \ldots \ldots \ldots \ldots \\
\quad(\text { Poa annua })\end{array}$ & 0.4 & 0.3 & 0.4 & 0.0 & 0.0 & 0.0 & 0.0 & 0.0 & 0.0 & 0.0 \\
\hline Carrots $(10) \ldots$ & 4.2 & 4.2 & $t$ & $\dagger$ & 0.0 & 0.0 & 0.0 & 0.0 & 0.0 & 0.0 \\
\hline Cotton $(2) \ldots \ldots$ & 5.2 & 1.7 & 1.8 & 0.8 & + & $\dagger$ & 0.0 & 0.0 & 0.0 & 0.0 \\
\hline $\begin{array}{l}\text { Crabgrass }(10) \ldots \ldots \ldots \\
\quad \text { (Digitaria } \text { sp. })\end{array}$ & 8.5 & 7.5 & 3.1 & 4.2 & 3.1 & 0.0 & 0.0 & 0.0 & 0.0 & 0.0 \\
\hline Flax $(10) \ldots \ldots \ldots \ldots \ldots$ & 4.4 & 4.5 & 4.1 & $\dagger$ & $\dagger$ & $t$ & 0.0 & 0.0 & 0.0 & 0.0 \\
\hline Oats $(10) \ldots \ldots \ldots \ldots \ldots$ & 8.9 & 8.6 & 7.4 & 1.5 & 0.7 & 0.0 & 0.0 & 0.0 & 0.0 & 0.0 \\
\hline Peas $(3) \ldots \ldots \ldots \ldots$ & 14.5 & 12.9 & 13.7 & 3.6 & $\dagger$ & $\dagger$ & 0.0 & 0.0 & 0.0 & 0.0 \\
\hline Sugar beets $(10) \ldots \ldots$ & 10.1 & 8.7 & 1.1 & 1.0 & 0.5 & $t$ & $\dagger$ & $\dagger$ & $t$ & $\dagger$ \\
\hline Sunflower $(2) \ldots \ldots \ldots$ & 16.6 & 16.8 & 1.3 & 2.1 & $t$ & $t$ & $t$ & $t$ & $t$ & $t$ \\
\hline $\begin{array}{c}\text { Watergrass (10)......... } \\
\quad \text { (Echinocloa Crusgalli) }\end{array}$ & 3.3 & 4.3 & $t$ & $t$ & $\dagger$ & 0.0 & 0.0 & 0.0 & 0.0 & 0.0 \\
\hline Watermelons (2)......... & 6.3 & 9.7 & 1.5 & 0.9 & 0.8 & 0.7 & 0.0 & 0.0 & 0.0 & 0.0 \\
\hline
\end{tabular}

* Figures in parentheses indicate number of plants harvested.

† Germination occurred normally, but subsequent growth was inhibited.

\section{TABLE 7}

Fresh and Dry Weights of Shoots and Roots of Five Kanota Oat Plants Grown in Soll Leachates and Culture Solution*

\begin{tabular}{|c|c|c|c|c|c|c|}
\hline \multirow{2}{*}{ Solution } & \multicolumn{3}{|c|}{ Fresh weights } & \multicolumn{3}{|c|}{ Dry weights } \\
\hline & Roots & Shoots & Total & Roots & Shoots & Total \\
\hline \multirow{2}{*}{\multicolumn{7}{|c|}{ Aiken soil: }} \\
\hline & & & & & & \\
\hline First increase...... & 5.6 & 2.1 & 7.7 & 0.45 & 0.4 & 0.95 \\
\hline Second increase ............ & 4.6 & 1.4 & 6.0 & 0.35 & 0.4 & 0.75 \\
\hline Third increase............. & 3.7 & 1.2 & 4.9 & 0.3 & 0.3 & 0.60 \\
\hline \multicolumn{7}{|l|}{ Yolo soil: } \\
\hline First increase........ & 1.6 & 0.7 & 2.3 & 0.2 & 0.25 & 0.45 \\
\hline Second increase $\ldots \ldots \ldots \ldots \ldots \ldots$ & 1.4 & 0.8 & 2.2 & 0.15 & 0.3 & 0.45 \\
\hline Third increase............... & 1.3 & 1.0 & 2.3 & 0.15 & 0.3 & 0.45 \\
\hline Hoagland solution $\ldots \ldots \ldots \ldots \ldots \ldots$ & 19.7 & 13.6 & 33.3 & 1.4 & 3.35 & 4.75 \\
\hline Distilled water. ................ & 3.2 & 1.0 & 4.2 & 0.2 & 0.3 & 0.5 \\
\hline
\end{tabular}

* Yolo soil solution contained displaced maleic hydrazide from leaching experiments. 
TABLE 8

Fresh Weights of Shoots and Roots of Five Kanota Oat Plants Grown in Three Nutrient Levels of Water Culiture Solutions Containing VARIOUs QUANTITIES OF MALEIC HYDRAZIDE

\begin{tabular}{|c|c|c|c|c|c|c|}
\hline \multirow{2}{*}{$\begin{array}{l}\text { Maleic hydrazide in p.p.m. } \\
\text { (culture solution basis) }\end{array}$} & \multicolumn{2}{|c|}{$0.5 \mathrm{H}$} & \multicolumn{2}{|c|}{$1.0 \mathrm{H}$} & \multicolumn{2}{|c|}{$2.0 \mathrm{H}$} \\
\hline & Roots & Shoots & Roots & Shoots & Roots & Shoots \\
\hline & $(w t, g m)$ & $(w t, g m)$ & $(w t, g m)$ & $(w t, g m)$ & $(w t, g m)$ & $(w t, g m)$ \\
\hline $0.0 \ldots \ldots \ldots \ldots \ldots \ldots \ldots \ldots$ & 15.7 & 10.9 & 23.1 & 26.9 & 19.7 & 33.0 \\
\hline $40.0 \ldots \ldots \ldots \ldots \ldots \ldots \ldots \ldots$ & 0.8 & 0.6 & 0.7 & 0.4 & 0.3 & 1.1 \\
\hline
\end{tabular}

TABLE 9

Length of Leaves of Kanota Oats Growing in Water Culture Solutions Containing Maleic Hydrazide Three, Six, and Ten Days afTer Transplanting

\begin{tabular}{|c|c|c|c|c|c|c|c|c|c|}
\hline & \multicolumn{9}{|c|}{ Number of days after transplanting } \\
\hline & \multicolumn{3}{|c|}{ Three } & \multicolumn{3}{|c|}{ Six } & \multicolumn{3}{|c|}{ Ten } \\
\hline & \multicolumn{9}{|c|}{ Concentration of maleic hydrazide } \\
\hline & 0.0 & 5.0 & 15.0 & 0.0 & 5.0 & 15.0 & 0.0 & 5.0 & 15.0 \\
\hline First leaf $(\mathrm{cm}) \ldots$ & 12.0 & 13.5 & 13.0 & 12.0 & 14.0 & 13.0 & 12.0 & 14.0 & 13.0 \\
\hline Second leaf $(\mathrm{cm})$. & 7.0 & 9.0 & 7.0 & 18.0 & 21.0 & 14.0 & 22.0 & 22.0 & 14.0 \\
\hline Third leaf $(\mathrm{cm})$. & 8.0 & 4.0 & 0.0 & 23.0 & 21.0 & 0.0 & 35.0 & 21.0 & 0.0 \\
\hline
\end{tabular}

TABLE 10

Fresh Weights of Shoots and Roots of Five Kanota Oat Plants Grown in Hoagland Complete Solution with Various CONCENTRATIONS OF MALEIC HYDRAZIDE

\begin{tabular}{|c|c|c|c|c|c|c|c|}
\hline & \multicolumn{7}{|c|}{ Concentration maleic hydrazide, p.p.m., culture solution basis } \\
\hline & 0.0 & 0.5 & 1.0 & 2.5 & 5.0 & 10.0 & 20.0 \\
\hline & $(w t, g m)$ & $(w t, g m)$ & $(w t, g m)$ & $(w t, m g)$ & $(w t, g m)$ & $(w t, g m)$ & $(w t, g m)$ \\
\hline Roots.... & 20.0 & 26.1 & 23.6 & 16.0 & 5.0 & 1.2 & 0.8 \\
\hline Shoots... & 28.3 & 29.4 & 30.1 & 25.8 & 9.5 & 2.5 & 1.4 \\
\hline Total.... & 48.3 & 55.5 & 53.7 & 41.8 & 14.5 & 3.7 & 2.2 \\
\hline
\end{tabular}

TABLE 11

Length of Shoots and Roots of Kanota OAt Plants Grown in Hoagland Complete Culture Solution Containing Maleic Hydrazide

(Values are averages of five plants)

\begin{tabular}{|c|c|c|c|c|c|c|c|}
\hline & \multicolumn{7}{|c|}{ Concentration maleic hydrazide, p.p.m., culture solution basis } \\
\hline & 0.0 & 0.5 & 1.0 & 2.5 & 5.0 & 10.0 & 20.0 \\
\hline & (length, $\mathrm{cm})$ & (length, cm) & $($ length, $\mathrm{cm})$ & (length, $\mathrm{cm}$ ) & (length, $\mathrm{cm})$ & $($ length, $\mathrm{cm})$ & (length, $\mathrm{cm})$ \\
\hline Roots.. & 16.0 & 22.0 & 16.0 & 14.0 & 5.0 & 13.0 & 13.0 \\
\hline Shoots........ & 32.0 & 44.0 & 35.0 & 43.0 & 39.0 & 15.0 & 13.0 \\
\hline
\end{tabular}


TABLE 12

Fresh Weights and Heights of Shoots of 10 Kanota Oat Plants Grown in 11 California SoIls Containing Varying Concentrations of MALEIC HydRAZide

(Values are averages of three replicates)

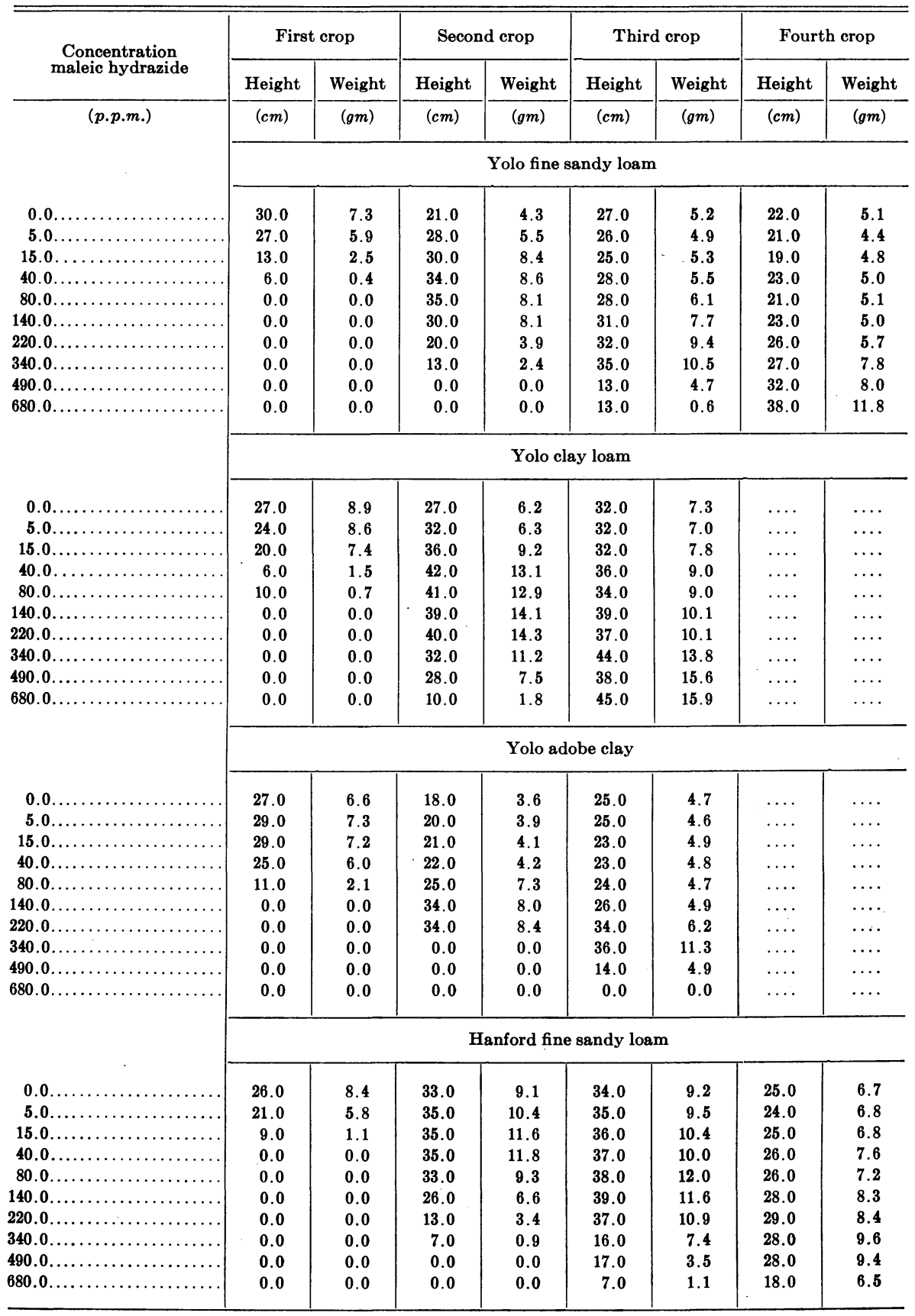


TABLE 12-Continued

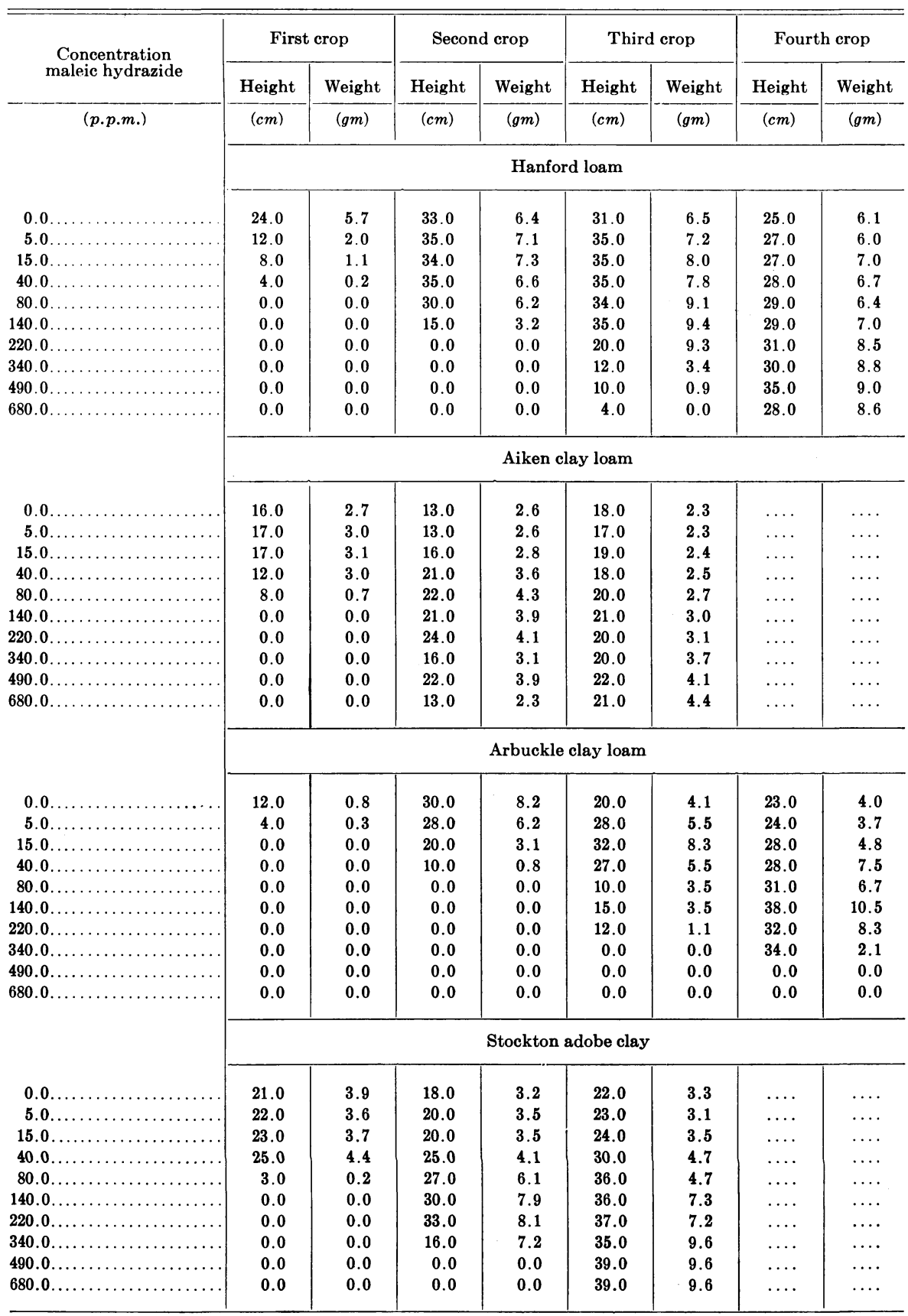


TABLE 12-Concluded

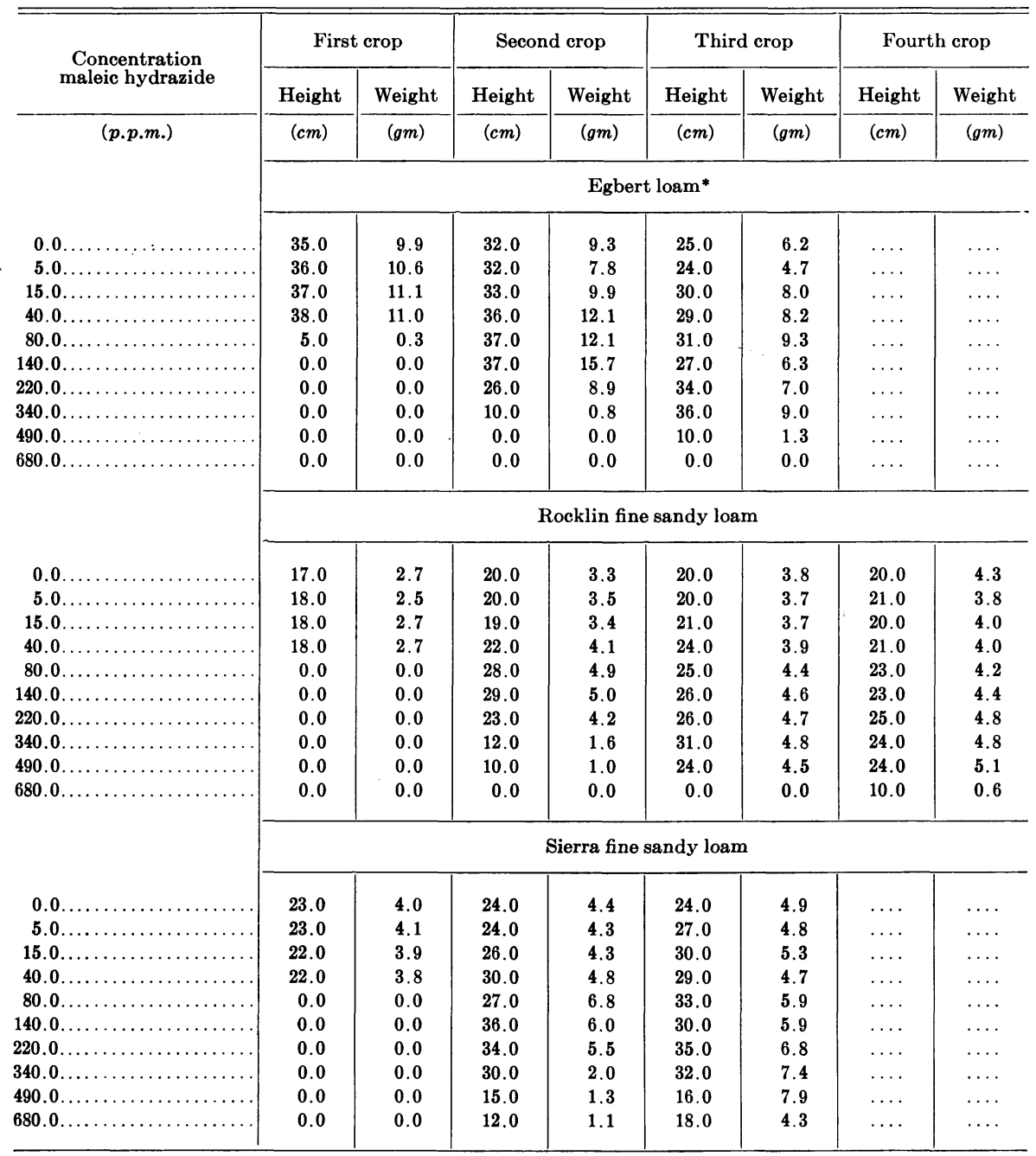

* Washed with excess water. 
TABLE 13

Fresh Weights and Heights of 10 Kanota Oat Plants Grown in Columns of Aiken Chay Loam Containing Varying P.P.M. of Maleic Hydrazide.

\begin{tabular}{|c|c|c|c|c|c|c|c|c|c|c|}
\hline \multirow{4}{*}{ Depth } & \multicolumn{10}{|c|}{ Aiken clay loam } \\
\hline & \multicolumn{6}{|c|}{ First crop } & \multicolumn{4}{|c|}{ Second crop } \\
\hline & \multicolumn{2}{|c|}{220.0 p.p.m. } & \multicolumn{2}{|c|}{440.0 p.p.m. } & \multicolumn{2}{|c|}{880.0 p.p.m. } & \multicolumn{2}{|c|}{440.0 p.p.m. } & \multicolumn{2}{|c|}{880.0 p.p.m. } \\
\hline & Height & Weight & Height & Weight & Height & Weight & Height & Weight & Height & Weight \\
\hline$(\mathrm{cm})$ & $(\mathrm{cm})$ & $(g m)$ & $(\mathrm{cm})$ & $(g m)$ & $(\mathrm{cm})$ & (gm) & $(\mathrm{cm})$ & (gm) & (cm) & $(g m)$ \\
\hline $0.0-10.0 \ldots \ldots$ & 0.0 & 0.0 & 0.0 & 0.0 & 0.0 & 0.0 & 15.0 & 1.5 & 0.0 & 0.0 \\
\hline $10.0-20.0 \ldots$ & 0.0 & 0.0 & 0.0 & 0.0 & 0.0 & 0.0 & 20.0 & 3.4 & 0.0 & 0.2 \\
\hline $20.0-30.0$ & 0.0 & 0.0 & 0.0 & 0.0 & 0.0 & 0.0 & 17.0 & 3.3 & 6.0 & 0.3 \\
\hline $30.0-40.0$ & 10.0 & 1.6 & 0.0 & 0.0 & 0.0 & 0.0 & 14.0 & 3.2 & 15.0 & 2.2 \\
\hline $40.0-50.0$. & 13.0 & 2.0 & 4.0 & 0.4 & 0.0 & 0.0 & 15.0 & 3.2 & 10.0 & 1.3 \\
\hline $50.0-60.0$. & 13.0 & 2.3 & 17.0 & 1.7 & 0.0 & 0.0 & 16.0 & 3.4 & 14.0 & 2.7 \\
\hline $60.0-70.0$ & 14.0 & 2.8 & 16.0 & 1.8 & 0.0 & 0.0 & 15.0 & 2.7 & 14.0 & 2.4 \\
\hline $70.0-80.0$ & 14.0 & 2.7 & 17.0 & 1.7 & 17.0 & 2.1 & 15.0 & 3.4 & 18.0 & 3.4 \\
\hline $80.0-90.0 \ldots$ & 15.0 & 2.7 & 20.0 & 1.7 & 14.0 & 2.0 & 15.0 & 3.0 & 17.0 & 3.2 \\
\hline $90.0-100.0$ & 11.0 & 3.0 & 20.0 & 1.8 & 16.0 & 2.2 & 16.0 & 3.4 & 13.0 & 2.7 \\
\hline Checks. & 16.0 & 2.8 & 19.0 & 2.1 & 15.0 & 2.3 & 16.0 & 3.2 & 16.0 & 2.9 \\
\hline
\end{tabular}

TABLE 14

Fresh Weights and Heights of 10 Kanota Oat Plants grown in Columns of Alken Clay loam Containing 220.0 P.P.m. Maleic Hydrazide: and Also under Conditions in Which Phosphate Was AdDed Both before AND AFTER THE ADDITION OF MALEIC HYDRAZIDE

\begin{tabular}{|c|c|c|c|c|c|c|c|c|c|c|}
\hline \multirow{4}{*}{ Depth } & \multicolumn{10}{|c|}{ Aiken clay loam } \\
\hline & \multicolumn{6}{|c|}{ First crop } & \multicolumn{4}{|c|}{ Second crop } \\
\hline & \multicolumn{2}{|c|}{$\underset{\text { maleichydrazide }}{220.0 \text { p.p.m. }}$} & \multicolumn{2}{|c|}{$\begin{array}{c}\text { Phosphate } \\
\text { added after m.h. }\end{array}$} & \multicolumn{2}{|c|}{$\begin{array}{c}\text { Phosphate } \\
\text { added before } \\
\text { m.h. }\end{array}$} & \multicolumn{2}{|c|}{$\begin{array}{c}\text { Phosphate } \\
\text { added after } \\
\text { m.h. }\end{array}$} & \multicolumn{2}{|c|}{$\begin{array}{l}\text { Phosphate } \\
\text { added before } \\
\text { m.h. }\end{array}$} \\
\hline & Height & Weight & Height & Weight & Height & Weight & Height & Weight & Height & Weight \\
\hline (cm) & $(\mathrm{cm})$ & $(g m)$ & $(\mathrm{cm})$ & $(\mathrm{gm})$ & $(\mathrm{cm})$ & $(g m)$ & $(\mathrm{cm})$ & $(\mathrm{gm})$ & $(\mathrm{cm})$ & $(g m)$ \\
\hline $0.0-10.0 \ldots \ldots$ & 0.0 & 0.0 & 0.0 & 0.0 & 0.0 & 0.0 & 0.0 & 0.0 & 0.0 & 0.0 \\
\hline $10.0-20.0 \ldots$ & 0.0 & 0.0 & 0.0 & 0.0 & 0.0 & 0.0 & 0.0 & 0.0 & 0.0 & 0.0 \\
\hline $20.0-30.0 \ldots$ & 0.0 & 0.0 & 0.0 & 0.0 & 0.0 & 0.0 & 0.0 & 0.0 & 0.0 & 0.0 \\
\hline $30.0-40.0 \ldots$ & 10.0 & 1.6 & 0.0 & 0.0 & 0.0 & 0.0 & 0.0 & 0.0 & 0.0 & 0.0 \\
\hline $40.0-50.0 \ldots \ldots$ & 13.0 & 2.0 & 0.0 & 0.0 & 0.0 & 0.0 & 0.0 & 0.0 & 0.0 & 0.0 \\
\hline $50.0-60.0 \ldots \ldots$ & 13.0 & 2.3 & 0.0 & 0.0 & 0.0 & 0.0 & 24.0 & 6.8 & 0.0 & 0.0 \\
\hline $60.0-70.0 \ldots$ & 14.0 & 2.8 & 15.0 & 2.3 & 0.0 & 0.0 & 16.0 & 2.3 & 0.0 & 0.0 \\
\hline $70.0-80.0 \ldots$ & 14.0 & 2.7 & 16.0 & 2.5 & 0.0 & 0.0 & 16.0 & 2.8 & 0.0 & 0.0 \\
\hline $80.0-90.0 \ldots \ldots$ & 15.0 & 2.7 & 15.0 & 2.6 & 0.0 & 0.0 & 15.0 & 1.6 & 0.0 & 0.0 \\
\hline $90.0-100.0$. . & 11.0 & 3.0 & 15.0 & 2.5 & 0.0 & 0.0 & 16.0 & 2.5 & 0.0 & 0.0 \\
\hline Checks.. & 16.0 & 2.8 & 17.0 & 2.6 & 18.0 & 2.8 & 16.0 & 2.7 & 19.0 & 3.5 \\
\hline
\end{tabular}


TABLE 15

Fresh Weights and Heights of 10 Kanota Oat Plants Grown in Columns of Sierra Fine Sandy Loam Containing 220.0 P.P.M. MALEIC HYDRAZIDE

\begin{tabular}{|c|c|c|c|c|c|c|}
\hline \multirow{3}{*}{ Depth } & \multicolumn{6}{|c|}{ Sierra fine sandy loam } \\
\hline & \multicolumn{2}{|c|}{ First crop } & \multicolumn{2}{|c|}{ Second crop } & \multicolumn{2}{|c|}{ Third crop } \\
\hline & Height & Weight & Height & Weight & Height & Weight \\
\hline$(\mathrm{cm})$ & $(\mathrm{cm})$ & $(g m)$ & $(\mathrm{cm})$ & $(g m)$ & $(\mathrm{cm})$ & $(g m)$ \\
\hline $0.0-10.0 \ldots \ldots \ldots \ldots$ & 0.0 & 0.0 & 0.0 & 0.0 & 7.0 & 0.2 \\
\hline $10.0-20.0 \ldots \ldots \ldots \ldots$. & 0.0 & 0.0 & 0.0 & 0.0 & 13.0 & 1.4 \\
\hline $20.0-30.0 \ldots \ldots \ldots \ldots$ & 0.0 & 0.0 & 0.0 & 0.0 & 30.0 & 6.7 \\
\hline $30.0-40.0 \ldots \ldots \ldots \ldots \ldots \ldots \ldots, \ldots$ & 0.0 & 0.0 & 15.0 & 0.7 & 29.0 & 5.8 \\
\hline $40.0-50.0 \ldots \ldots \ldots \ldots \ldots \ldots \ldots \ldots \ldots \ldots$ & 0.0 & 0.0 & 27.0 & 6.6 & 32.0 & 5.9 \\
\hline $50.0-60.0 \ldots \ldots \ldots \ldots \ldots \ldots \ldots \ldots \ldots$ & 0.0 & 0.0 & 28.0 & 5.7 & 30.0 & 6.3 \\
\hline $60.0-70.0 \ldots \ldots \ldots \ldots \ldots \ldots \ldots \ldots \ldots$ & 0.0 & 0.0 & 28.0 & 6.0 & 32.0 & 6.7 \\
\hline 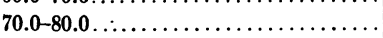 & 0.0 & 0.0 & 26.0 & 5.2 & 34.0 & 5.7 \\
\hline $80.0-90.0 \ldots \ldots \ldots \ldots \ldots \ldots \ldots \ldots$ & 0.0 & 0.0 & 24.0 & 4.5 & 32.0 & 7.2 \\
\hline $90.0-100.0 \ldots \ldots \ldots \ldots \ldots \ldots \ldots \ldots$ & 0.0 & 0.0 & 25.0 & 4.5 & 32.0 & 6.5 \\
\hline Checks.... & 25.0 & 3.5 & 23.0 & 4.1 & 33.0 & 5.8 \\
\hline
\end{tabular}


TABLE 16

Fresh Weights and Heights of 10 Kanota Oat Plants Grown in Columns of Six Different Solls Containing 220.0 P.P.M. MALEIC HYDRAZZIDE

\begin{tabular}{|c|c|c|c|c|}
\hline \multirow{2}{*}{ Depth } & \multicolumn{2}{|c|}{ First crop } & \multicolumn{2}{|c|}{ Second crop } \\
\hline & Height & Weight & Height & Weight \\
\hline \multirow[t]{2}{*}{$(\mathrm{cm})$} & $(\mathrm{cm})$ & $(g m)$ & $(\mathrm{cm})$ & $(g m)$ \\
\hline & \multicolumn{4}{|c|}{ Aiken clay loam } \\
\hline $0.0-10.0 \ldots$ & 0.0 & 0.0 & 20.0 & 5.0 \\
\hline $10.0-20.0 \ldots \ldots \ldots \ldots \ldots \ldots$ & 0.0 & 0.0 & 16.0 & 3.8 \\
\hline $20.0-30.0 \ldots \ldots \ldots \ldots$ & 0.0 & 0.0 & 13.0 & 2.9 \\
\hline $30.0-40.0 \ldots \ldots \ldots \ldots \ldots$ & 10.0 & 1.6 & 13.0 & 2.7 \\
\hline $40.0-50.0 \ldots \ldots \ldots \ldots$ & 13.0 & 2.0 & 13.0 & 2.5 \\
\hline $50.0-60.0 \ldots \ldots \ldots \ldots \ldots \ldots \ldots$ & 13.0 & 2.3 & 12.0 & 2.3 \\
\hline $60.0-70.0 \ldots \ldots \ldots \ldots \ldots \ldots$ & 14.0 & 2.8 & 12.0 & 2.7 \\
\hline $70.0-80.0 \ldots \ldots \ldots \ldots$ & 14.0 & 2.7 & 15.0 & 2.6 \\
\hline $80.0-90.0 \ldots \ldots \ldots \ldots \ldots$ & 15.0 & 2.7 & 16.0 & 2.7 \\
\hline $90.0-100.0 \ldots \ldots \ldots \ldots \ldots \ldots$ & 11.0 & 3.0 & 16.0 & 2.4 \\
\hline \multirow[t]{2}{*}{ Checks... } & 16.0 & 2.8 & 12.0 & 2.5 \\
\hline & \multicolumn{4}{|c|}{ Hanford loam } \\
\hline $0.0-10.0 \ldots$ & 0.0 & 0.0 & 30.0 & 11.1 \\
\hline $10.0-20.0 \ldots \ldots$ & 0.0 & 0.0 & 20.0 & 8.1 \\
\hline $20.0-30.0 \ldots \ldots \ldots$ & 0.0 & 0.0 & 15.0 & 5.2 \\
\hline $30.0-40.0 \ldots \ldots \ldots \ldots$ & 0.0 & 0.0 & 15.0 & 5.8 \\
\hline $40.0-50.0 \ldots \ldots \ldots \ldots$ & 0.0 & 0.0 & 10.0 & 1.8 \\
\hline $50.0-60.0 \ldots \ldots \ldots \ldots \ldots \ldots$ & 0.0 & 0.0 & 10.0 & 4.1 \\
\hline $60.0-70.0 \ldots \ldots \ldots \ldots$ & 0.0 & 0.0 & 10.0 & 0.4 \\
\hline $70.0-80.0 \ldots \ldots \ldots \ldots \ldots \ldots$ & 0.0 & 0.0 & 20.0 & 6.1 \\
\hline $80.0-90.0 \ldots \ldots \ldots \ldots \ldots \ldots$ & 0.0 & 0.0 & 20.0 & 7.1 \\
\hline $90.0-100.0 \ldots \ldots \ldots \ldots \ldots \ldots$ & 0.0 & 0.0 & 20.0 & 6.8 \\
\hline \multirow[t]{2}{*}{ Checks. } & 30.0 & 6.2 & 19.0 & 5.6 \\
\hline & \multicolumn{4}{|c|}{ Stockton adobe clay } \\
\hline $0.0-10.0$ & 0.0 & 0.0 & 20.0 & 6.3 \\
\hline $10.0-20.0 \ldots \ldots$ & 0.0 & 0.0 & 17.0 & 5.1 \\
\hline $20.0-30.0 \ldots \ldots \ldots \ldots \ldots \ldots \ldots$ & 0.0 & 0.0 & 20.0 & 5.2 \\
\hline $30.0-40.0 \ldots \ldots \ldots \ldots \ldots \ldots$ & 0.0 & 0.0 & 15.0 & 5.0 \\
\hline $40.0-50.0 \ldots \ldots \ldots \ldots \ldots \ldots$ & 0.0 & 0.0 & 20.0 & 4.8 \\
\hline $50.0-60.0 \ldots \ldots \ldots \ldots \ldots \ldots$ & 0.0 & 0.0 & 20.0 & 5.0 \\
\hline $60.0-70.0 \ldots \ldots \ldots \ldots \ldots \ldots$ & 0.0 & 0.0 & 18.0 & 5.1 \\
\hline $70.0-80.0 \ldots \ldots \ldots \ldots \ldots \ldots$ & 0.0 & 0.0 & 19.0 & 5.1 \\
\hline $80.0-90.0 \ldots \ldots \ldots \ldots \ldots \ldots$ & 8.0 & 0.9 & 19.0 & 4.8 \\
\hline $90.0-100.0 \ldots \ldots \ldots \ldots \ldots \ldots$ & 20.0 & 3.0 & 17.0 & 3.5 \\
\hline Checks.... & 20.0 & 3.3 & 14.0 & 2.8 \\
\hline
\end{tabular}


TABLE 16-Continued

\begin{tabular}{|c|c|c|c|c|}
\hline \multirow{2}{*}{ Depth } & \multicolumn{2}{|c|}{ First crop } & \multicolumn{2}{|c|}{ Second crop } \\
\hline & Height & Weight & Height & Weight \\
\hline \multirow[t]{2}{*}{$(\mathrm{cm})$} & $(\mathrm{cm})$ & $(g m)$ & $(\mathrm{cm})$ & $(g m)$ \\
\hline & \multicolumn{4}{|c|}{ Yolo clay loam } \\
\hline $0.0-10.0 \ldots \ldots \ldots \ldots \ldots \ldots \ldots \ldots \ldots \ldots \ldots \ldots \ldots$ & 0.0 & 0.0 & 5.0 & 0.5 \\
\hline $10.0-20.0 \ldots \ldots \ldots \ldots \ldots \ldots \ldots \ldots \ldots \ldots \ldots \ldots$ & 0.0 & 0.0 & 10.0 & 1.1 \\
\hline $20.0-30.0 \ldots \ldots \ldots \ldots \ldots \ldots \ldots \ldots \ldots \ldots \ldots \ldots$ & 0.0 & 0.0 & 10.0 & 0.9 \\
\hline $30.0-40.0 \ldots \ldots \ldots \ldots \ldots \ldots \ldots \ldots \ldots \ldots \ldots \ldots$ & 0.0 & 0.0 & 10.0 & 1.3 \\
\hline $40.0-50.0 \ldots \ldots \ldots \ldots \ldots \ldots \ldots \ldots \ldots \ldots \ldots \ldots$ & 0.0 & 0.0 & 6.0 & 0.6 \\
\hline $50.0-60.0 \ldots \ldots \ldots \ldots \ldots \ldots \ldots \ldots \ldots \ldots \ldots \ldots$ & 0.0 & 0.0 & 8.0 & 0.7 \\
\hline $60.0-70.0 \ldots \ldots \ldots \ldots \ldots$ & 0.0 & 0.0 & 8.0 & 0.9 \\
\hline $70.0-80.0 \ldots \ldots \ldots \ldots \ldots \ldots \ldots$ & 0.0 & 0.0 & 14.0 & 2.2 \\
\hline $80.0-90.0 \ldots \ldots \ldots \ldots \ldots \ldots \ldots$ & 0.0 & 0.0 & 11.0 & 2.7 \\
\hline $90.0-100.0 \ldots \ldots, \ldots \ldots \ldots \ldots \ldots \ldots \ldots \ldots \ldots$ & 0.0 & 0.0 & 14.0 & 1.1 \\
\hline \multirow[t]{2}{*}{ Checks.. } & 33.0 & 8.8 & 20.0 & 4.2 \\
\hline & \multicolumn{4}{|c|}{ Yolo clay loam (nitrate freè) } \\
\hline $0.0-10.0 \ldots \ldots \ldots \ldots \ldots \ldots$ & 0.0 & 0.0 & 8.0 & 0.6 \\
\hline $10.0-20.0 \ldots \ldots \ldots \ldots \ldots \ldots$ & 0.0 & 0.0 & 8.0 & 0.8 \\
\hline $20.0-30.0 \ldots \ldots \ldots \ldots \ldots \ldots \ldots \ldots \ldots \ldots \ldots \ldots \ldots \ldots$ & 0.0 & 0.0 & 6.0 & 0.5 \\
\hline $30.0-40.0 \ldots \ldots \ldots \ldots \ldots \ldots \ldots \ldots \ldots \ldots \ldots \ldots$ & 0.0 & 0.0 & 6.0 & 0.3 \\
\hline $40.0-50.0 \ldots \ldots \ldots \ldots \ldots \ldots \ldots \ldots \ldots \ldots \ldots \ldots$ & 0.0 & 0.0 & 4.0 & 0.2 \\
\hline $50.0-60.0 \ldots \ldots \ldots \ldots \ldots \ldots \ldots \ldots \ldots \ldots \ldots \ldots$ & 0.0 & 0.0 & 8.0 & 0.8 \\
\hline $60.0-70.0 \ldots \ldots \ldots \ldots \ldots \ldots \ldots \ldots \ldots \ldots \ldots \ldots$ & 0.0 & 0.0 & 10.0 & 0.8 \\
\hline $70.0-80.0 \ldots \ldots \ldots \ldots \ldots \ldots \ldots$ & 0.0 & 0.0 & 4.0 & 0.4 \\
\hline $80.0-90.0 \ldots \ldots \ldots \ldots \ldots \ldots \ldots \ldots \ldots \ldots \ldots \ldots$ & 0.0 & 0.0 & 10.0 & 1.1 \\
\hline $90.0-100.0 \ldots \ldots \ldots \ldots \ldots \ldots \ldots \ldots \ldots \ldots \ldots \ldots \ldots \ldots \ldots \ldots$ & 0.0 & 0.0 & 12.0 & 1.6 \\
\hline \multirow[t]{2}{*}{ Checks... } & 33.0 & 8.8 & 17.0 & 3.9 \\
\hline & \multicolumn{4}{|c|}{ Yolo fine sandy loam } \\
\hline $0.0-10.0 \ldots \ldots \ldots \ldots \ldots \ldots \ldots \ldots \ldots \ldots \ldots \ldots$ & 0.0 & 0.0 & 13.0 & 2.1 \\
\hline $10.0-20.0 \ldots \ldots \ldots \ldots \ldots \ldots \ldots \ldots \ldots \ldots \ldots \ldots$ & 0.0 & 0.0 & 25.0 & 9.4 \\
\hline $20.0-30.0 \ldots \ldots \ldots \ldots \ldots \ldots \ldots \ldots \ldots \ldots \ldots \ldots$ & 0.0 & 0.0 & 22.0 & 7.2 \\
\hline $30.0-40.0 \ldots \ldots \ldots \ldots \ldots \ldots \ldots \ldots \ldots \ldots \ldots \ldots$ & 0.0 & 0.0 & 20.0 & 6.3 \\
\hline $40.0-50.0 \ldots \ldots \ldots \ldots \ldots \ldots \ldots \ldots \ldots \ldots \ldots \ldots$ & 0.0 & 0.0 & 18.0 & 5.9 \\
\hline $50.0-60.0 \ldots \ldots \ldots \ldots \ldots \ldots \ldots \ldots \ldots \ldots \ldots \ldots$ & 0.0 & 0.0 & 15.0 & 6.2 \\
\hline 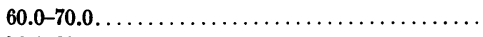 & 0.0 & 0.0 & 25.0 & 10.3 \\
\hline $70.0-80.0 \ldots \ldots \ldots \ldots \ldots \ldots \ldots \ldots \ldots \ldots \ldots \ldots$ & 0.0 & 0.0 & 25.0 & 9.6 \\
\hline $80.0-90.0 \ldots \ldots \ldots \ldots \ldots \ldots \ldots \ldots \ldots \ldots \ldots \ldots$ & 0.0 & 0.0 & 10.0 & 1.5 \\
\hline 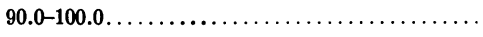 & 0.0 & 0.0 & 25.0 & 7.5 \\
\hline Checks.................................. & 33.0 & 7.6 & 20.0 & 4.2 \\
\hline
\end{tabular}




\section{TABLE 17}

Fresh Weights and Heights of First Crop of Kanota Oats Plants Grown in Columns of Yolo Fine Sandy Loam Containing 220.0 P.P.M. PER Colum Which WaS Then Leached WITH 150 SURFACE CeNTIMETERS OF Water

\begin{tabular}{|c|c|c|}
\hline \multirow{2}{*}{ Depth } & \multicolumn{2}{|c|}{ Yolo fine sandy loam } \\
\hline & Height & Weight \\
\hline$(\mathrm{cm})$ & $(\mathrm{cm})$ & $(g m)$ \\
\hline 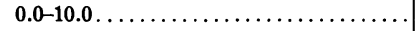 & 38.0 & 15.4 \\
\hline $10.0-20.0 \ldots \ldots \ldots \ldots \ldots \ldots \ldots \ldots \ldots \ldots$ & 36.0 & 10.7 \\
\hline $20.0-30.0 \ldots \ldots \ldots \ldots \ldots \ldots \ldots \ldots \ldots \ldots$ & 28.0 & 7.3 \\
\hline $30.0-40.0 \ldots \ldots \ldots \ldots \ldots \ldots \ldots \ldots \ldots \ldots$ & 26.0 & 5.1 \\
\hline $40.0-50.0 \ldots \ldots \ldots \ldots \ldots \ldots \ldots \ldots \ldots$ & 25.0 & 4.3 \\
\hline 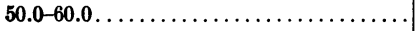 & 28.0 & 4.3 \\
\hline $60.0-70.0 \ldots \ldots \ldots \ldots \ldots \ldots \ldots \ldots \ldots \ldots$ & 28.0 & 4.3 \\
\hline $70.0-80.0 \ldots \ldots \ldots \ldots \ldots \ldots \ldots \ldots \ldots \ldots$ & 25.0 & 4.2 \\
\hline 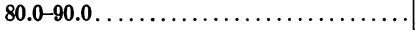 & 0.0 & 0.0 \\
\hline $90.0-100.0 \ldots \ldots \ldots \ldots \ldots \ldots \ldots \ldots \ldots \ldots$ & 0.0 & 0.0 \\
\hline Checks..$\ldots \ldots \ldots \ldots \ldots \ldots \ldots \ldots$ & 28.0 & 6.7 \\
\hline
\end{tabular}

TABLE 18

Fresh Weights and Heights of Kanota Oat Plants Grown in Columns of Aiken Clay loam Containing Two Concentrations of Maleic HydRAZIDE THAT WAS LEACHED WITH INCREASING AMOUNTS OF WATER

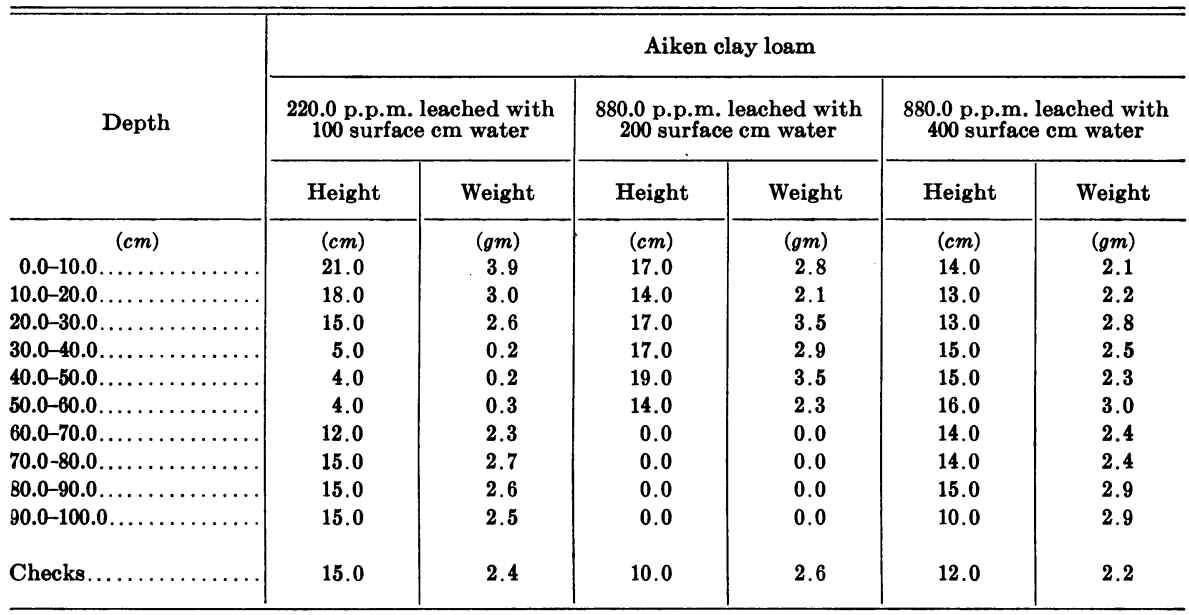




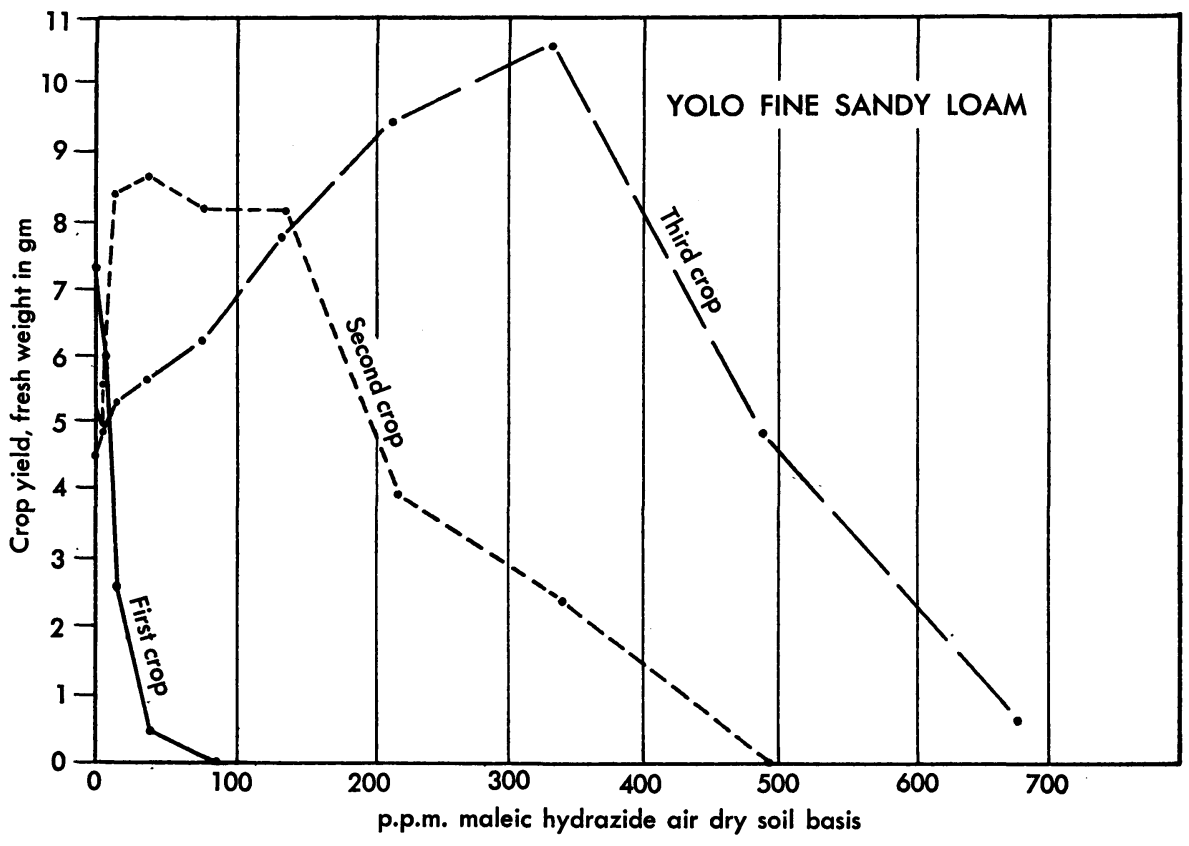

Fig. 1. 'Toxicity of maleic hydrazide in Yolo fine sandy loam. 


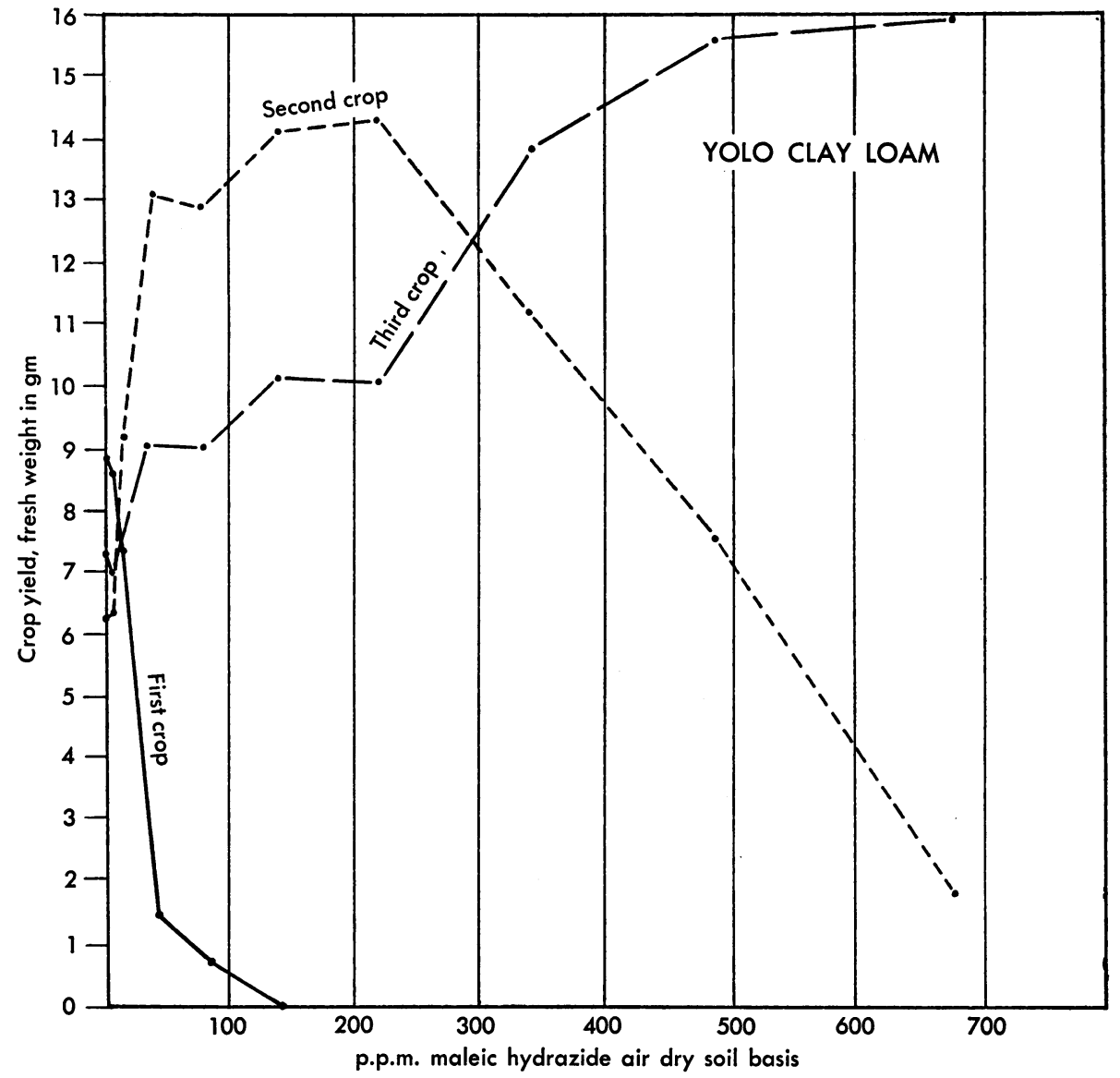

Fig. 2. Toxicity of maleic hydrazide in Yolo clay loam. 


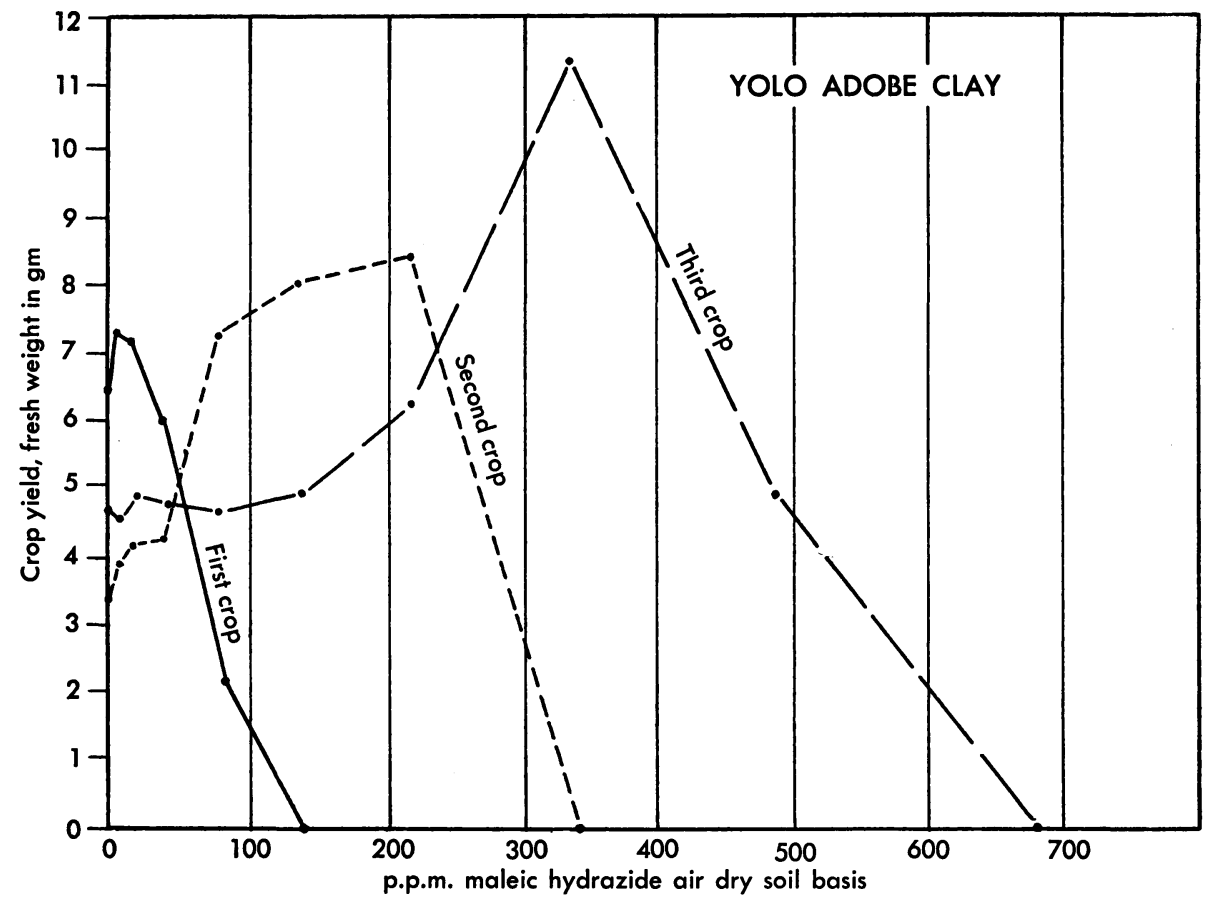

Fig. 3. Toxicity of maleic hydrazide in Yolo adobe clay.

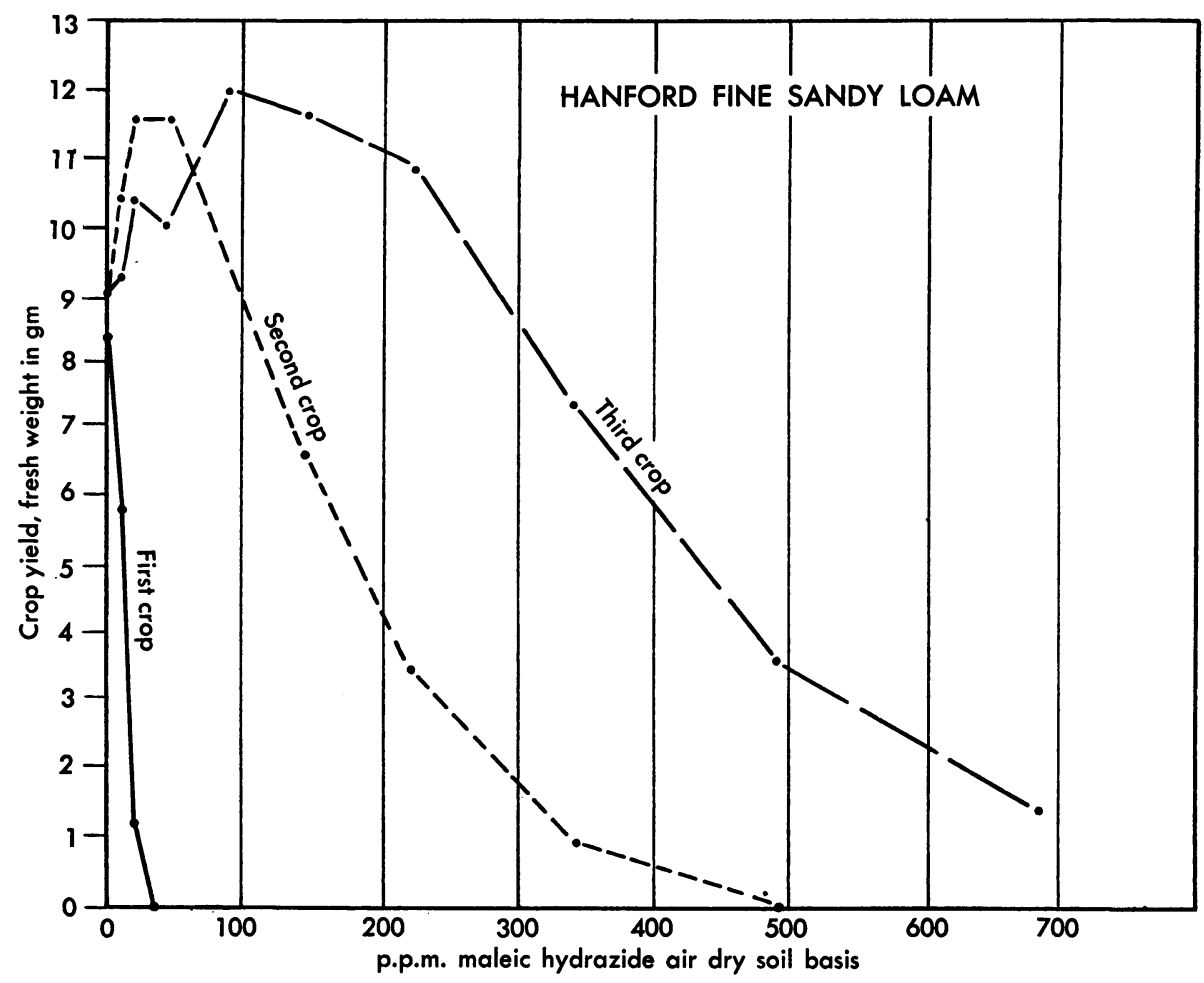

Fig. 4. Toxicity of maleic hydrazide in Hanford fine sandy loam. 


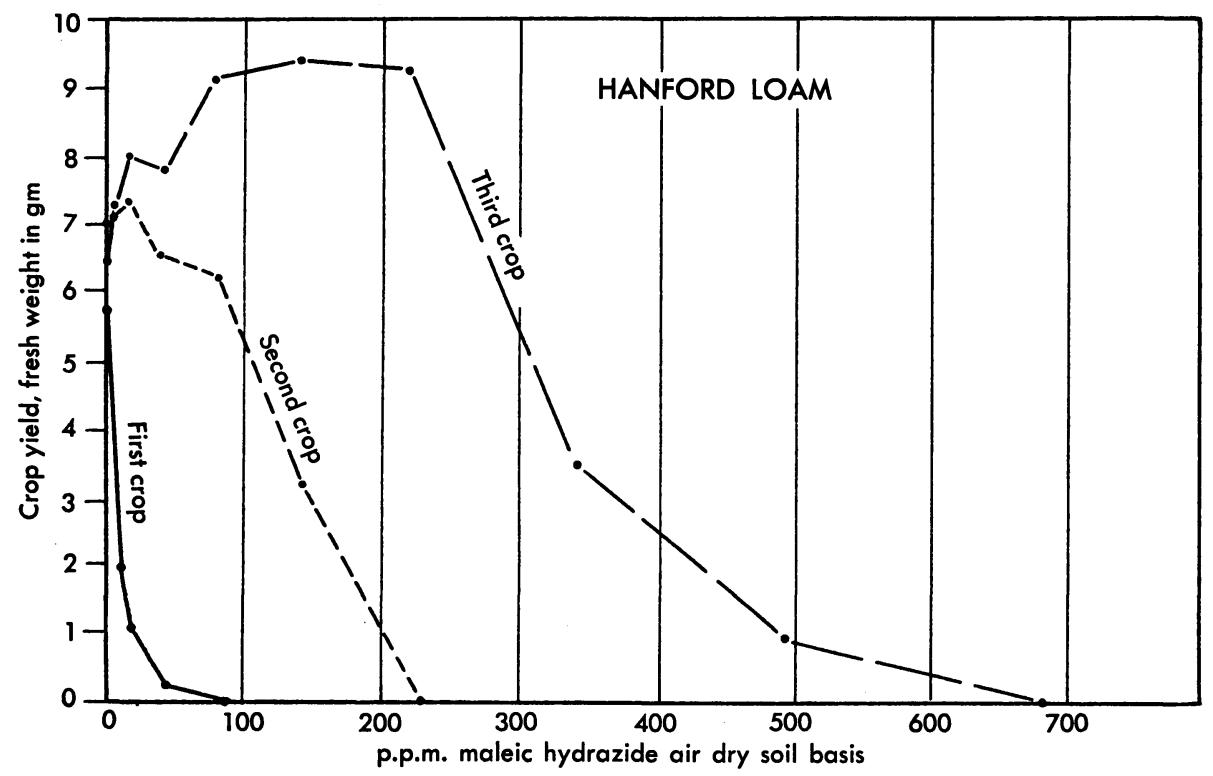

Fig. 5. Toxicity of maleic hydrazide in Hanford loam.

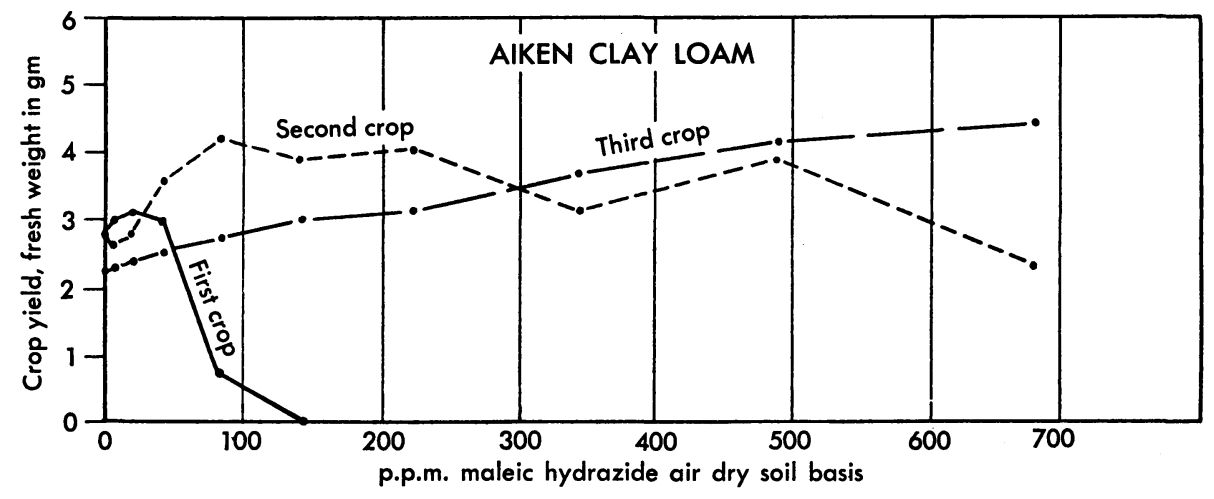

Fig. 6. Toxicity of maleic hydrazide in Aiken clay loam. 


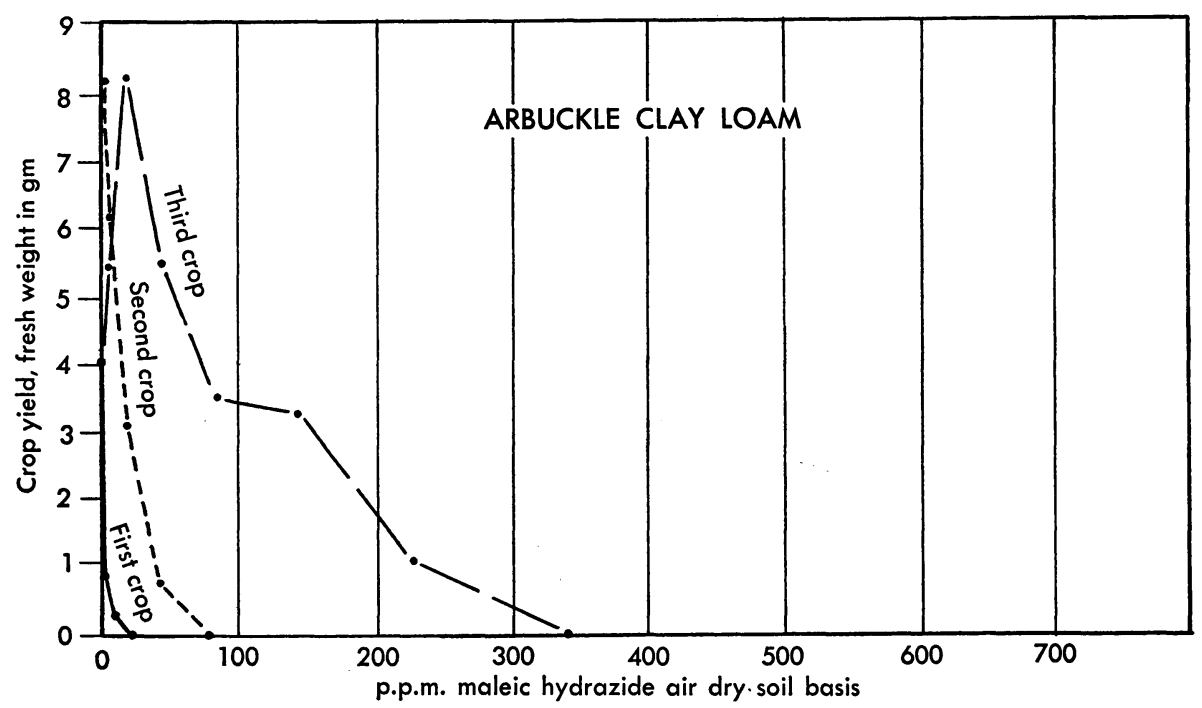

Fig. 7. Toxicity of maleic hydrazide in Arbuckle clay loam.

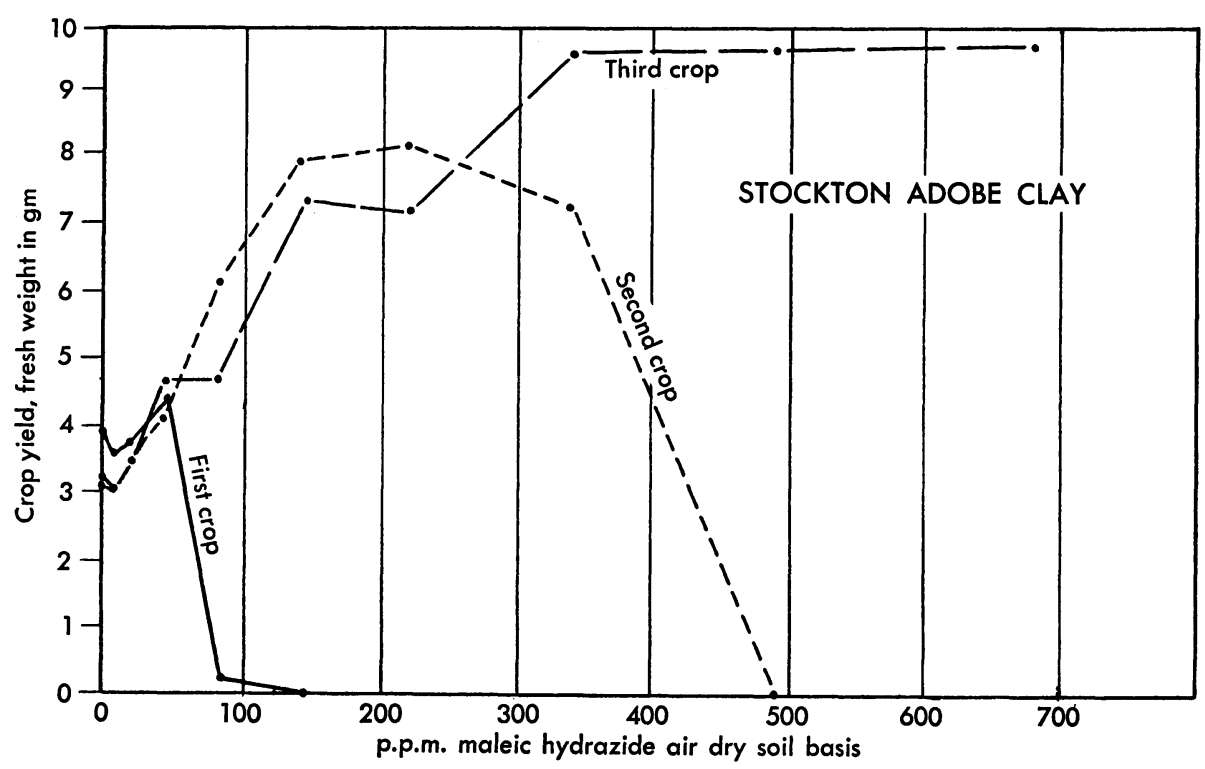

Fig. 8. Toxicity of maleic hydrazide in Stockton adobe clay. 


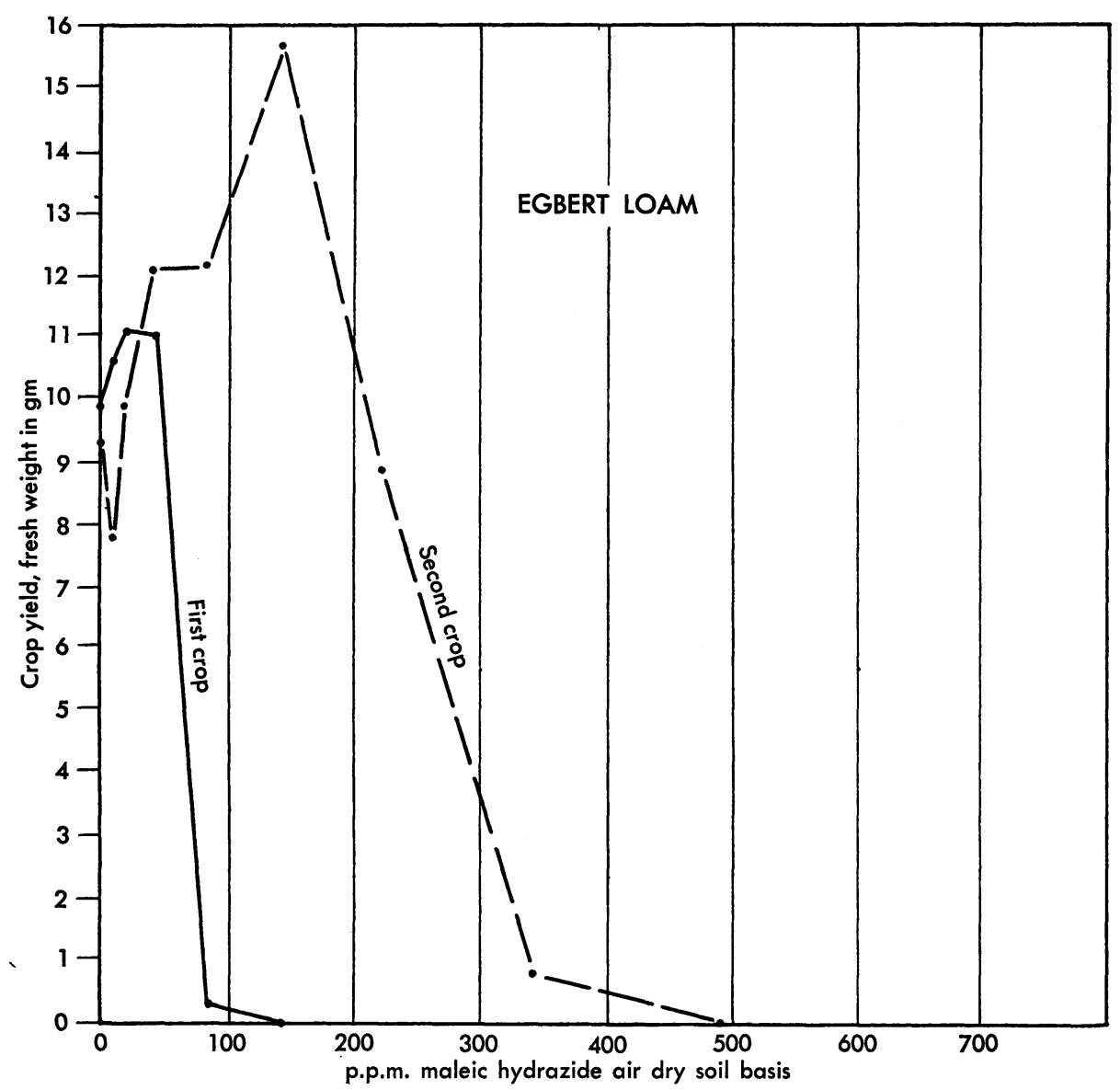

Fig. 9. Toxicity of maleic hydrazide in Egbert loam previously leached with water.

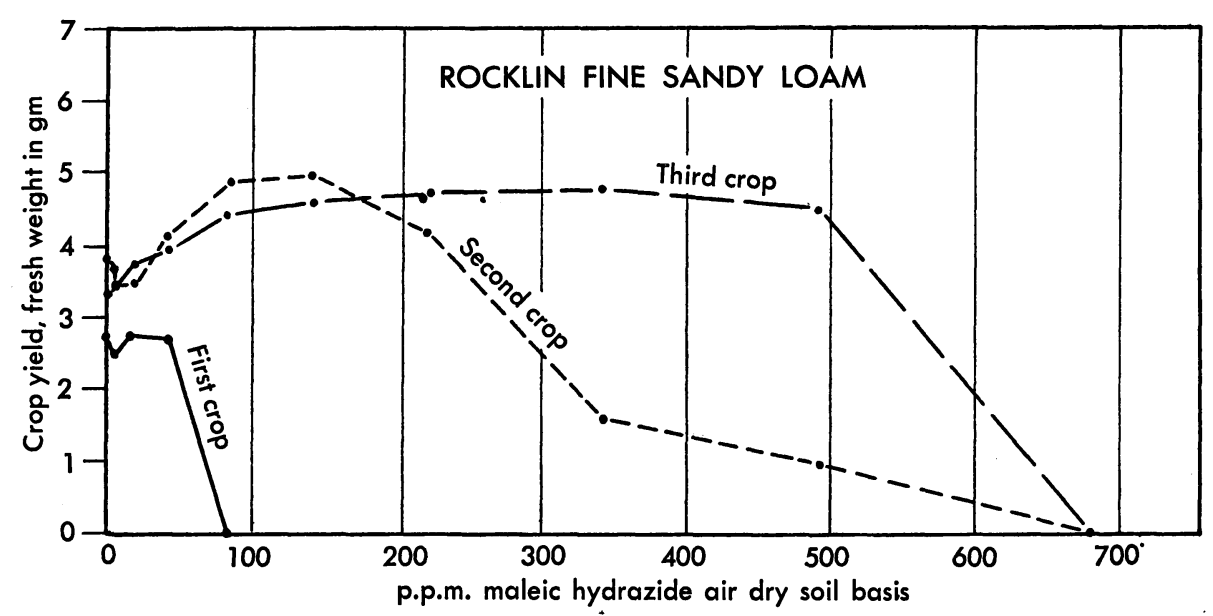

Fig. 10. Toxicity of maleic hydrazide in Rocklin fine sandy loam. 


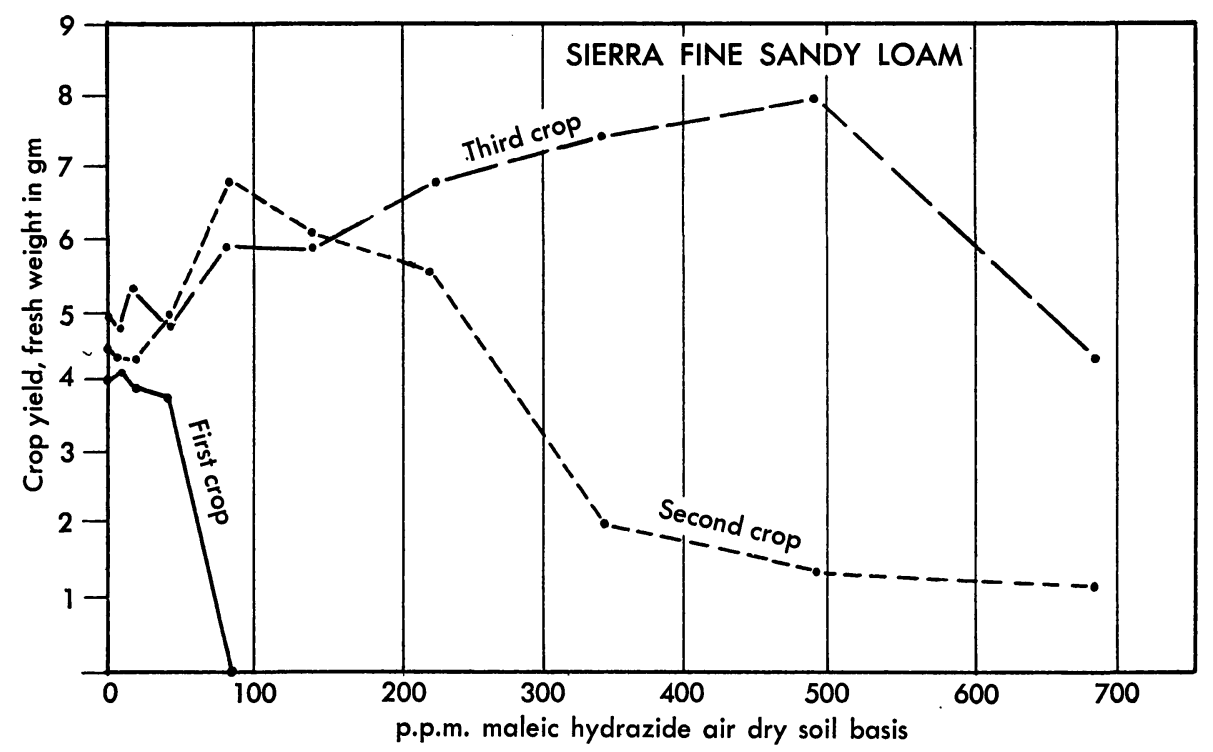

Fig. 11. Toxicity of maleic hydrazide in Sierra fine sandy loam. 

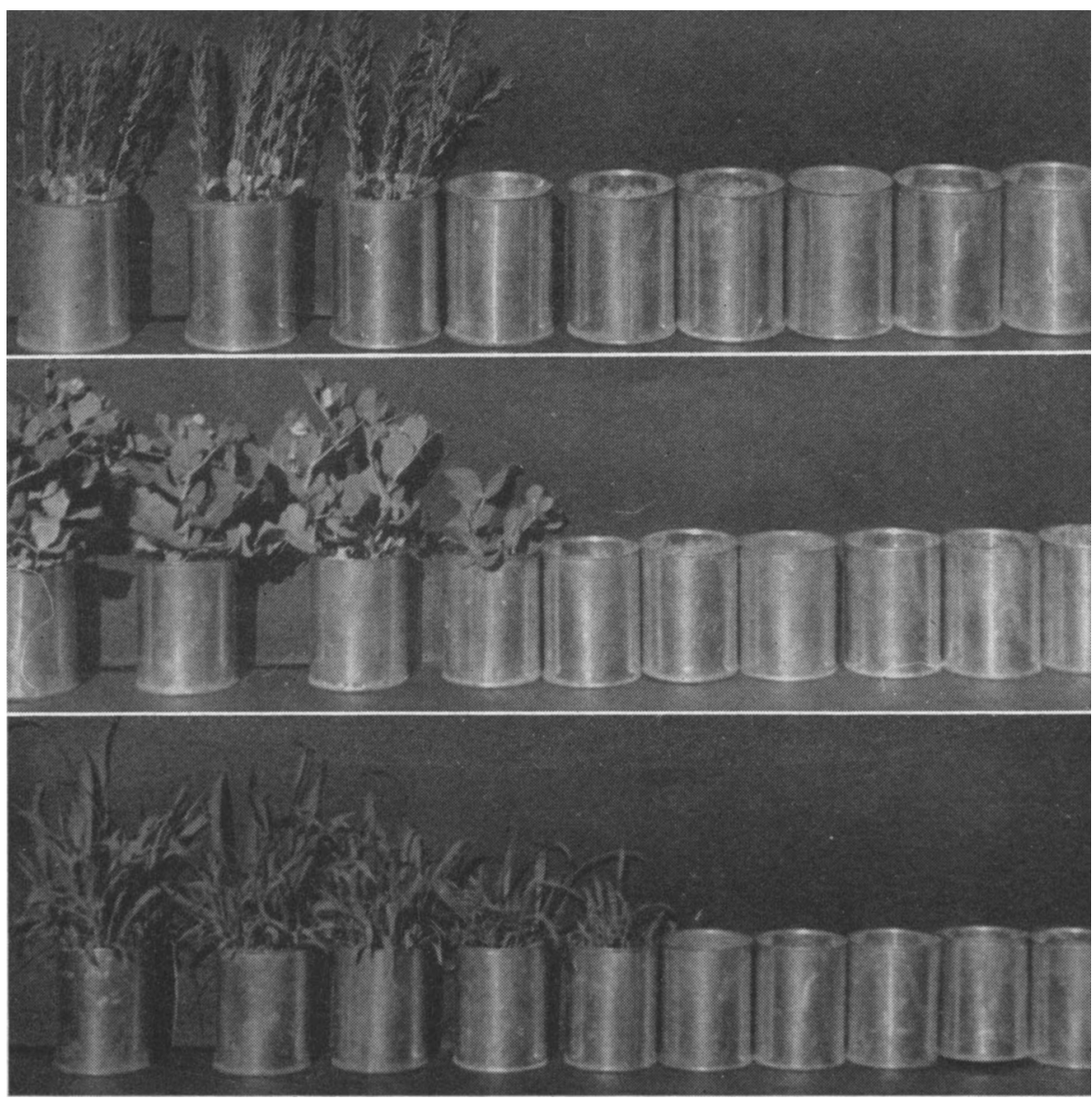

Plate 1. Toxicity of maleic hydrazide in Yolo clay loam, first crop. Top to bottom: flax, peas, and crabgrass (Digitaria sp.). Left to right: $0.0 ; 5.0 ; 15.0 ; 40.0 ; 80.0 ; 140.0 ; 220.0$; 340.0 ; 490.0 ; and 680.0 p.p.m. maleic hydrazide added, air dry soil basis. 


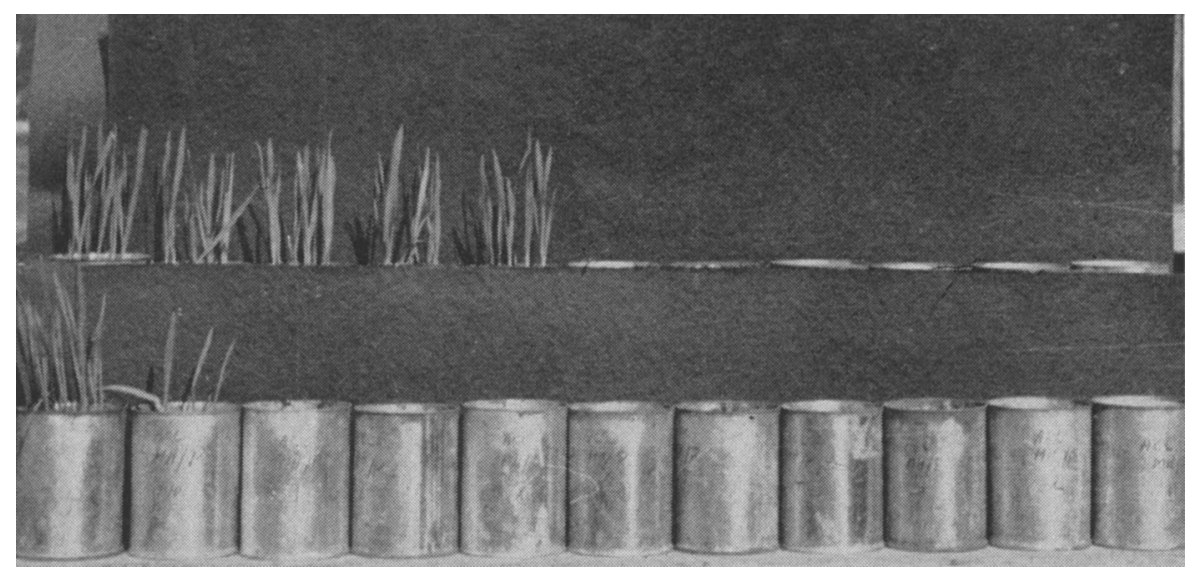

Plate 2. Distribution of maleic hydrazide in Aiken clay loam treated with $\mathrm{KH}_{2} \mathrm{PO}_{4}$; first crop, 12 days after planting. Top: soil saturated with phosphate after addition of 220.0 p.p.m. maleic hydrazide; bottom: soil saturated with phosphate before addition of 220.0 p.p.m. maleic hydrazide. Left to right: control; $100-90 ; 90-80 ; 80-70 ; 70-60 ; 60-50$; $50-40 ; 40-30 ; 30-20 ; 20-10 ; 10-0.0 \mathrm{cms}$ depth. 

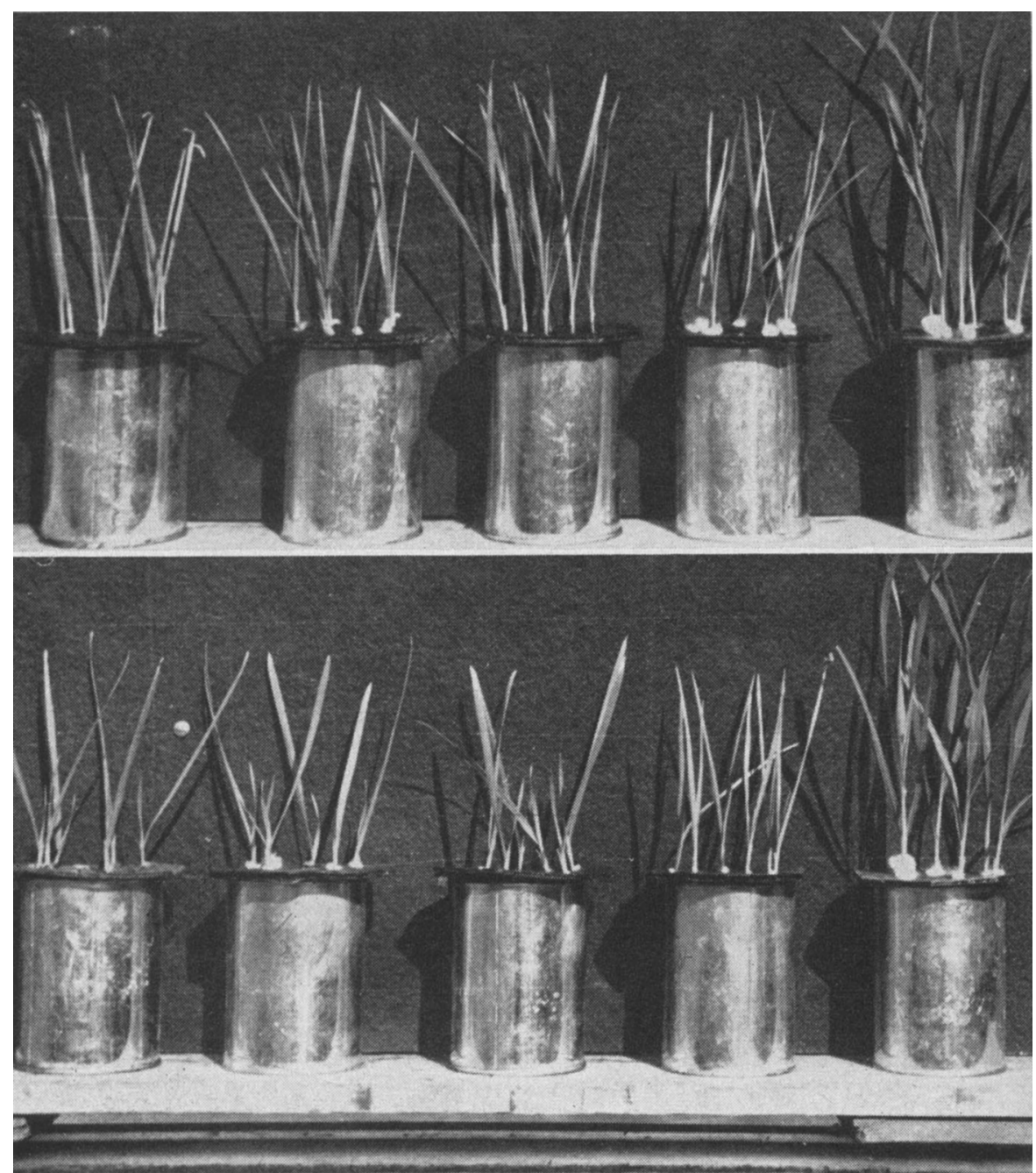

Plate 3. Comparing growth of Kanota oats in soil and "Hoagland" solutions. Top: Aiken soil solution without maleic hydrazide; bottom: Yolo fine sandy loam soil solution containing maleic hydrazide. Right to left: Full Hoagland, distilled water, soil solutions. Note leaf length. 


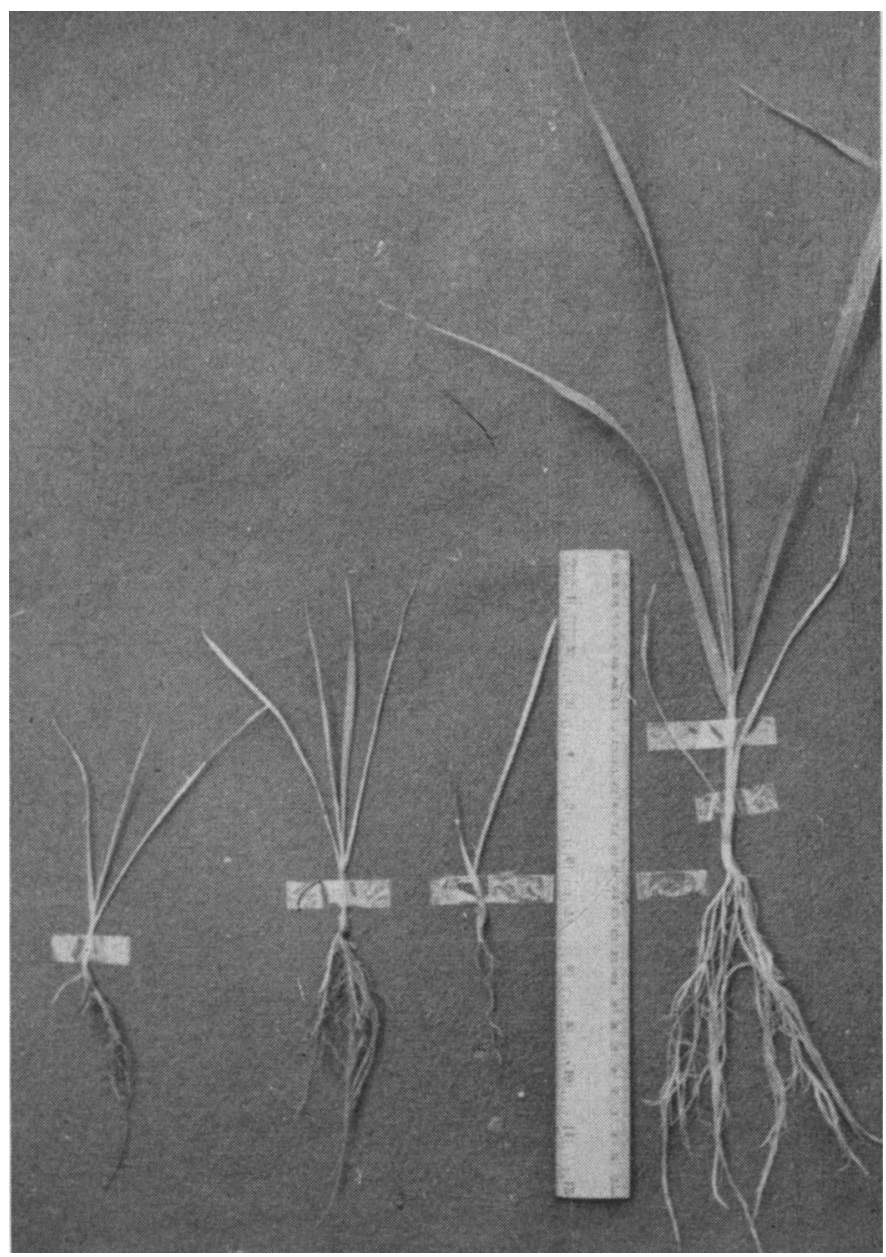

Plate 4. Kanota oat plants grown in soil solutions and nutrient culture solution (30 days after starting). Right to left: complete Hoagland solution; Yolo soil solution (contains maleic hydrazide); Aiken soil solution (no maleic hydrazide present); and distilled water. 

The journal Hilgardia is published at irregular intervals, in volumes of about 600 pages. The number of issues per volume varies.

Subscriptions are not sold. The periodical is sent as published only to libraries, or to institutions in foreign countries having publications to offer in exchange.

You may obtain a single copy of any issue free, as long as the supply lasts; please request by volume and issue number from:

\section{Publications Office \\ College of Agriculture \\ Berkeley 4, California}

The limit to nonresidents of California is 10 separate issues on a single order. A list of the issues still available will be sent on request.

In order that the information in our publications may be more intelligible, it is sometimes necessary to use trade names of products or equipment rather than complicated descriptive or chemical identifications. In so doing, it is unavoidable in some cases that similar products which are on the market under other trade names may not be cited. No endorsement of named products is intended nor is criticism implied of similar products which are not mentioned. 